PART 1

Articles 



\title{
Using the Master's Tools to Dismantle the Master's House: International Law and Palestinian Liberation
}

\author{
Ralph Wilde
}

\section{Contents}

I Introduction

II Occupation and Occupation Law

III Law on the Use of Force, Including its Interface with the Law on Title to Territory

IV Self-determination as a Legal Right

V Self-determination Delayed and Potentially Dropped

VI Self-determination Obscured

VII Erosion of Legal Standards?

VIII Conclusion

\section{Introduction}

In 2018, Al-Haq and the Muwatin Institute organized two international law conferences at Birzeit University in Palestine. ${ }^{1}$ Al-Haq took some of the attendees at the first conference, including the present author, to meet the Jahalin Palestinian Bedouin community of Khan al-Ahmar, in al-Quds Governorate of the West Bank. The Jahalin settled there in the 195os, when the West Bank was under Jordanian control, having been expelled from al-Naqab by the Israeli army in 1948. After Israel captured the West Bank in 1967, the Israeli settlements of Ma'ale Adumim and Kfar Adumim were established in the adjacent areas to Khan al-Ahmar. Israel treated the Jahalin as illegitimate

1 See Al-Haq, International Conference: The Threshold from Occupation to Annexation, Oct. 3-4, 2018, https://www.alhaq.org/advocacy/6155.html; and Birzeit University, Annual Muwatin Conference reviews seven decades of the Universal Human Rights Declaration (Oct. 10, 2018), https://www.birzeit.edu/en/news/annual-muwatin-conference-reviews-seven -decades-universal-human-rights-declaration. 
residents, refusing to connect them to utilities, notably water, sanitation, and electricity. This created a situation of acute material deprivation. Eventually, Israel forcibly evicted residents and demolished their houses. At the time of the visit, the remaining residents were under threat of forced eviction and relocation to an area near the refuse dump of Abu Dis, in a different part of al-Quds Governorate. ${ }^{2}$ At the meeting, community leader Amran Reshaq stated that it is a common misconception to think that Palestinian communities like his want merely to improve their humanitarian conditions in their place of residence - for example, by having proper access to water. Instead, he insisted, their primary demand is to return to the place from where they were displaced.

Amran Reshaq's crucial distinction between the underlying situation and improving conditions within the situation is the focus of this article. The theme of Al-Haq conference was the threshold from occupation to annexation. ${ }^{3}$ The theme of the Muwatin conference was the 7oth Anniversary of the Universal Declaration of Human Rights (UDHR). ${ }^{4}$ These themes implicate the three main areas of generally-applicable international law commonly invoked in relation to the situation of the Palestinian people. Legal "tools" deployed to dismantle the "master's house" of colonial oppression, to borrow from Audre Lorde. ${ }^{5}$ First is the law on the use of force, including the interface between this area of law and the law on title to territory. ${ }^{6}$ Second is the law of armed conflict/international humanitarian law (IHL), including occupation

2 See, e.g., Al-Haq, Al-Haq Urgent Appeal to the United Nations Special Rapporteur on Adequate Housing as a Component of the Right to an Adequate Standard of Living, and on the Right to Non-Discrimination in This Context (May 28, 2018), https://www.alhaq.org/advocacy/6194. html; Khan al-Ahmar: Israel court approves demolition of Bedouin village, BBC News (Sep. 5, 2018), https://www.bbc.com/news/world-middle-east-45420915; Alice M. Panepinto, Jurisdiction as Sovereignty Over Occupied Palestine, 26 Soc. \& Legal Stud. 311 (2017); B'Tselem, Communities facing expulsion: The Khan al-Ahmar area (Oct. 10, 2017), https://www.btselem .org/communities_facing_expulsion/khan_al_ahmar; Al-Haq, Plight of Palestinian Bedouin depicts impact of illegal Israeli occupation and practices in Palestinian Territory (Dec. 17, 2014), https://www.alhaq.org/publications/8068.html.

3 See above n1.

4 See above nı. Universal Declaration of Human Rights, U.N. Doc. A/RES/3/217A (Dec. 10, 1948) [hereinafter UDHR].

5 Audre Lorde, The Master's Tools Will Never Dismantle the Master's House, in Sister Outsider: Essays and Speeches (1984) [hereinafter Lorde (1984)].

6 The authorities are voluminous and references to them readily available. For helpful lists, see Oxford University Press, Oxford Bibliographies-Use of Force in International Law [hereinafter OUP UoF list (2020)], https://www.oxfordbibliographies.com/view/document/obo -9780199796953/obo-9780199796953-0oo5.xml; Oxford University Press, Oxford Bibliographies -Territorial Title [hereinafter OUP Territorial Title list (2016)], https://www.oxfordbibliogra phies.com/view/document/obo-978o199796953/obo-978o199796953-ooo4.xml. Further particular sources on these areas of international law are cited below. 
law. ${ }^{7}$ Third is international human rights law (IHRL), including the right of self-determination. ${ }^{8}$ Thus, Amnesty International UK invokes IHRL as central to the work of Amnesty International generally, ${ }^{9}$ and describes this work in the Palestinian context as aimed at bringing an "end" to the "oppression" of the Palestinian people..$^{10}$ Related to this common association of international law with emancipatory objectives is the idea that if only the law were enforced, emancipation would be realized. Or, put differently, that the lack of Palestinian liberation is due to the violation of the law with impunity. Thus, for Amnesty, the oppression of the Palestinian people has occurred despite its "campaigning hard ... for the last 5 o years." ${ }^{11}$ What is being implied is that if such a campaign were to be successful, the objective of bringing "oppression" to an "end" would be realized.

But the international legal system is embedded with the ideology and techniques of imperialism and colonialism. ${ }^{12}$ This includes in its operation through, and assumption of the legitimacy of, the division of the world into sovereign states, and, often, the basis on which it determines how boundaries are drawn. ${ }^{13}$ Is international law not, then, part of the "master's house"? Would

The primary and secondary authorities are voluminous and references to them readily available. For helpful lists, see Oxford University Press, Oxford Bibliographies - International Humanitarian Law [hereinafter OUP IHL list (2017)], https://www.oxfordbibliographies .com/view/document/obo-978o199796953/obo-978o199796953-0146.xml; Oxford University Press, Oxford Bibliographies-Military Occupation [hereinafter OUP Occupation list (2017)], https://www.oxfordbibliographies.com/view/document/obo-978o199796953/obo -9780199796953-0077.xml. Further particular sources on these areas of international law are cited below.

8 The primary and secondary authorities are voluminous and references to them readily available. For a helpful list, see Oxford University Press, Oxford Bibliographies-Human Rights [hereinafter OUP HR list (2017)], https:/www.oxfordbibliographies.com/view/ document/obo-978o199796953/obo-9780199796953-0056.xml. Further particular sources on these areas of international law are cited below.

9 See Amnesty International UK, Human rights law (July 20, 2018) [hereinafter Amnesty International UK (2018)], https://www.amnesty.org.uk/human-rights-law.

10 See Amnesty International UK, Help end the 50 year oppression of Palestinians [hereinafter Amnesty International UK (2019)], https://web.archive.org/web/20210516051751/https:// www.amnesty.org.uk/campaign/palestinian-crisis-appeal-carousel.

11 See id.

12 See, e.g., Antony Anghie, Imperialism, Sovereignty, and the Making of International Law (2005) [hereinafter Anghie (2005)]; B.S. Chimni, Third World Approaches to International Law: A Manifesto, 8 Int'l Comty. L. Rev. 3 (2006) [hereinafter Chimni (2006)]; James Thuo Gathii, TWAIL: A Brief History of its Origins, its Decentralized Network, and a Tentative Bibliography, 3 Trade L. \& Dev. 26 (2011); and, on borders in particular, see Makau Mutua, Why Redraw the Map of Africa: A Moral and Legal Inquiry, 16 Mich. J. Int'l L. 1113 (1994) [hereinafter Mutua (1994)].

13 See the discussion below, text accompanying n121. 
the implementation of international law necessarily bring about Palestinian liberation? More fundamentally, is the conservative social institution of law compatible with transformatory emancipation? Lorde insists that "... the master's tools will never dismantle the master's house."14 She cautions that "they may allow us temporarily to beat him at his own game, but they will never enable us to bring about genuine change." 15

Given these challenges, the present article provides a critical evaluation of what is at stake when international law is invoked in the context of the Palestinian struggle. ${ }^{16}$ How and to what extent does it speak to Amran Reshaq's claim?

The article is divided as follows. Section 2 identifies a predominant, and at times exclusive, focus on IHL, including occupation law, when international advocates address the Palestinian struggle. Relatedly, there is an exclusive focus on the occupation itself. This excludes key elements of the Palestinian struggle arising out of the creation of Israel in 1948. Specifically, it bypasses the question of the situation of the Palestinian people vis-à-vis the territory of Israel, whether they are Israeli citizens or refugees displaced during the Nakba (such as the Jahalin). Moreover, even within this limited focus, the exclusive invocation of occupation law ignores entirely, because of the narrow scope of that law, the question of the existential legitimacy of the occupation itself.

The article then discusses the two areas of international law that address this existential legitimacy - the law on the use of force and the law of selfdetermination - and how they interface with the law on title to territory

\footnotetext{
14 Lorde (1984), above $\mathrm{n}_{5}$.

15 Id
}

16 The focus is on general international law only, not also the specific legal arrangements that are also relevant to the Palestinian situation, such as United Nations Security Council (UNSC) and General Assembly (UNGA) resolutions, the Oslo Peace Accords, etc. (although such resolutions are mentioned when they are significant to the general international legal framework). For critical evaluations encompassing further features of the legal framework, see, e.g., Ardi Imseis, The United Nations and the Question of Palestine: A Study in International Legal Subalternity (Sep. 2018) (doctoral thesis, Cambridge University) to be published as The United Nations and the Question of Palestine: Rule by Law and the Structure of International Legal Subalternity (CUP, forthcoming 2022) [hereinafter Imseis (2018/2022)]; F. Yahia, The Palestine Question and International Law, Palestine Liberation Organization Research Center (1970) [hereinafter Yahia (1970)]; Ardi Imseis, Negotiating the Illegal: On the United Nations and the Illegal Occupation of Palestine, 1967-2020, 31 Eur. J. Int'l L. 1055 (2020) [hereinafter Imseis (2020)]; Noura Erakat, Justice for Some: Law and the Question of Palestine (2019) [hereinafter Erakat (2019)]; Hani Sayed, The Fictions of the 'Illegal' Occupation in the West Bank and Gaza, 16 Or. Rev. Int'l L. 79 (2014) [hereinafter Sayed (2014)]; Conference report, "Law and Politics: Options and Strategies of International Law for the Palestinian People" - Birzeit [Proceedings], 17 Palestine Y.B. Int'l L. 141 (2014) [hereinafter 2014 Birzeit Conference]; John Reynolds, Anti-Colonial Legalities: Paradigms, Tactics \& Strategy, 18 Palestine Y.B. Int'l L. 8 (2015) [hereinafter Reynolds (2015)]. 
when it comes to annexation. Section 3 begins with annexation. International law provides a seemingly clear repudiation of the legitimacy of this as far as Israel and the West Bank (including East Jerusalem) is concerned. However, despite what some commentators suggest, such a position does not necessarily delegitimize the continuance of the occupation. To completely address the applicable normative framework, one must account for the self-defense component of the law on the use of force. Regrettably, most commentators seem unwilling to appraise the occupation's legitimacy in these terms. Yet such an appraisal, provided herein, reveals that the occupation is an illegal use of force - aggression - and must therefore be terminated. The problem, however, is that engaging with this crucial argument requires the Palestinian people to frame their case in terms of the legitimacy, or otherwise, of Israel's security requirements in justifying the occupation. The focus is thus on Israel's needs, not their own situation.

Section 4 turns to the law of self-determination, which provides in its "external" manifestation an alternative basis for framing arguments, ostensibly orientated towards freedom for the Palestinian people. However, the right is commonly presented as restricted to the model of sovereign statehood as the basis for collective Palestinian identity. Moreover, this statehood is itself limited to the territory of West Bank and Gaza. The territorial limitation excludes (like the earlier limited focus on the occupation) the situation of the Palestinian people with respect to the rest of the land between the river and the sea.

Even within the limited exclusive focus on the West Bank and Gaza, Palestinian self-determination has not been realized in over half a century of occupation. Experts and commentators tend to make that point, sometimes (but not always) call for the occupation to end, then conclude their analysis. But there are additional relevant factors to the denial of Palestinian self-determination beyond the basic fact of the occupation. And these factors can be identified in aspects of how international law is understood and applied.

To appreciate this, it is helpful to broaden the focus to other situations where people entitled to external self-determination have also been denied the realization of this - for example, the Sahrawi, who have been under Moroccan occupation since 1975. This is done in Section 5. A link is made to these practices and the racist, patriarchal concept of trusteeship over people: the idea that a people are granted freedom only if they are deemed "ready." The notion of a conditional entitlement to freedom has been identified by Ardi Imseis in the UN treatment of Palestinian liberation. ${ }^{17}$ Here, freedom is contingent on the reaching of a peace agreement. However, international law ostensibly framed self-determination as a repudiation of trusteeship over people and its racist 
underpinnings. According to this, independence was supposed to be realized immediately. How, then, has this idea been re-introduced in the "post-colonial" era and applied to the Palestinian people?

One explanation is the failure to appreciate the full significance of the law on the use of force. Section 6, however, offers additional explanations. Three factors have the effect of downgrading and even bypassing the question of realizing Palestinian self-determination. In the first place, is the exclusive focus on occupation law, and the characterization of the situation as an "occupation." In the second place, further features of the application of the trusteeship-over-people concept are relevant. These include distinctions sometimes made between situations designated as "colonial," and those designated as "occupations," with the concept somehow applying differently between the two categories. In the third place, is the jurisprudence of IHRL that includes self-determination as a "human right" in the two main global human rights treaties. Section 6 evaluates the practice of the two United Nations (UN) committees monitoring the implementation of those treaties, and the positions taken by leading international human rights NGOs: Amnesty International and Human Rights Watch. This analysis reveals a tendency to ignore the existential legitimacy of the occupation and the significance to this of the self-determination right. Relatedly, they treat the right of return of the Palestinian people in a problematic way. Moreover, these bodies' approaches to the Palestinian people's "internal" self-determination within Israel implies an affirmation of the collective self-determination entitlement of the people of Israel. The ironic nature of the bypassing of the collective Palestinian self-determination entitlement - in the context of an implied affirmation of this right for the people of the very state responsible for preventing the entitlement from being realized - adds insult to injury.

Finally, Section 7 considers whether the foregoing might not be understood only in terms of the existing international legal status quo - that self-determination is being violated and this violation is being ignored. Alternatively, might it suggest that the norms themselves are being altered? The Trump administration's recognitions of Israel's purported annexation of the Syrian Golan Heights and Morocco's purported annexation of Western Sahara, and the moving of the United States (US) Israeli embassy to Jerusalem (maintained by the Biden administration), potentially suggest an effort at normative challenge. The Section considers the issues at stake here, including the implications for the silence of the international human rights committees and NGOs on external self-determination.

Throughout the article, the discussion makes comparative references to other relevant situations of occupation/denial of self-determination/illegal annexation, such as the occupations of Germany, Austria, and Japan after the 
Second World War; ${ }^{18}$ the Moroccan occupation and purported annexation of the Western Sahara; ${ }^{19}$ the Indonesian occupation and purported annexation between 1975 and 1999, and subsequent UN administration, between 1999 and 2002, of Timor Leste; ${ }^{20}$ the Russian occupation and purported annexation of Crimea since 2014; ${ }^{21}$ the US-United Kingdom (UK)-led Coalition Provisional Authority (CPA) occupation of Iraq 2003-2004 and subsequent military presence; ${ }^{22}$ and the Israeli occupation and purported annexation of the Syrian Golan Heights. ${ }^{23}$

\section{Occupation and Occupation Law}

The UDHR, whose 7oth anniversary was the theme of the Muwatin conference, was adopted in 1948 as part of the broader post-1945 law-making efforts on humanitarian issues which included the 1949 Geneva Conventions. ${ }^{24}$ These treaties, notably the Fourth Convention, contain key rules on occupation

18 See, e.g., the sources cited in Ralph Wilde, International Territorial Administration: How Trusteeship and the Civilizing Mission Never Went Away (2008) [hereinafter Wilde (2008)], at 21, 23-5, 275 n140, 295, 309, 323, 328-9, 369-70, \& 428.

19 See, e.g., Western Sahara, Advisory Opinion, 1975 I.C.J. Rep. 12 (Oct. 16) [hereinafter ICJ Western Sahara Advisory Opinion]; Wilde (2008), above n18, Ch. 5, Section 5.6 (and sources cited therein); Rainer Hofmann, Annexation, Max Planck Encyc. Pub. Int'l L. (Jan. 2020) [hereinafter Hofmann (2020)], para. 37 (and sources cited therein), https:// opil.ouplaw.com/view/10.1093/law:epil/978o19923169o/law-978o19923169o-e1376; and the UNSC resolutions discussed below, text accompanying n148 et seq.

20 See, e.g., Wilde (2008), above n18, passim (see the index entry for East Timor, at 580), and Sources list, at 514 et seq. On the Indonesian occupation in particular, see International Law and the Question of East Timor (Catholic Institute for International Relations, 1995).

21 See, e.g., Thomas D. Grant, Annexation of Crimea, 109 Am. J. Int'l L. 68, 68-95 (2015) (and sources cited therein).

22 See, e.g., Adam Roberts, Transformative military occupation: Applying the laws of war and human rights, 100 Am. J. Int'l L. 580 (2006) [hereinafter Roberts (2006)]; Stefan Talmon, The Occupation of Iraq (2020); Matilda Arvidsson, The Subject in International Law: The Administrator of the Coalition Provisional Authority of Occupied Iraq and its Laws (2016); David J. Scheffer, Beyond Occupation Law, 97 Am. J. Int'l L. 842 (2003) [hereinafter Scheffer (2003)]; Eyal Benvenisti, The International Law of Occupation Ch. 9 (2nd ed., 2012) [hereinafter Benvenisti (2012)]; Kerry Rittich, Occupied Iraq: Imperial Convergences? 31 Leiden J. Int'l L 479 (2018).

23 See Hoffman (2020), above nı, para. 33 (and sources cited therein).

24 UDHR, above n4. Geneva Convention (I) for the Amelioration of the Condition of the Wounded and Sick in Armed Forces in the Field, Aug. 12, 1949, 75 U.N.T.S. 31 [hereinafter First Geneva Convention]; Geneva Convention (II) for the Amelioration of the Condition of the Wounded, Sick and Shipwrecked Members of Armed Forces at Sea, Aug. 12, 1949, 75 U.N.T.S. 85 [hereinafter Second Geneva Convention]; Geneva Convention(III) Relative to the Treatment of Prisoners of War, Aug. 12, 1949, 75 U.N.T.S. 135 [hereinafter Third Geneva 
law, implicating the theme of the Al-Haq conference. They form part of the international law regulating the conduct of warfare - the jus in bello. The Geneva Conventions supplemented the occupation law norms of the Hague Regulations of 1899 and $1907 .{ }^{25}$ This is understood to form part of a broader paradigm shift, from a state-centric, bombs-and-bullets "law of armed conflict" paradigm to a supposedly human-centered, humanizing approach. ${ }^{26}$ Hence the alteration in the name being associated with this area of law, "international humanitarian law." The general assertion of humanitarianism is then associated with occupation law in particular. So, the legal department of the International Committee of the Cross (ICRC), the self-appointed guardian of this body of law, asserts that "the law of occupation is primarily motivated by humanitarian considerations." ${ }^{27}$

This association with humanitarianism paves the way for the predominant or exclusive focus on IHL, including occupation law, in discussions of legal questions and advocacy strategies aimed at vindicating the Palestinian people's rights. Such an approach is typically followed by "internationals" working in Palestine, whether for foreign states, international organizations, or NGOs. For example, the Swedish NGO Diakonia, which states that its international work generally is concerned with ending "poverty and oppression," conducts its work in Palestine exclusively within an IHL-orientated framework. ${ }^{28}$

Convention]; Geneva Convention (IV) Relative to the Protection of Civilian Persons in Time of War, Aug. 12, 1949, 75 U.N.T.S. 287 [hereinafter Fourth Geneva Convention].

25 Hague Convention (II) with Respect to the Laws and Customs of War on Land, annex: Regulations concerning the Laws and Customs of War on Land, July 29, 1899, 26 Martens Nouveau Recueil (ser. 2) 949 [hereinafter 1899 Hague Regulations], especially Section III; Hague Convention IV - Laws and Customs of War on Land, annex: Regulations concerning the Laws and Customs of War on Land, Oct. 18, 1907, 3 Martens Nouveau Recueil (ser. 3) 461 [hereinafter 1907 Hague Regulations], especially Section III.

26 For this evolution, see the sources cited in: OUP IHL list (2017), above n7.

27 ICRC, Occupation and international humanitarian law: questions and answers (Aug. 4, 2004), https://www.icrc.org/en/doc/resources/documents/misc/634kfc.htm.

28 On the general international work of Diakonia, see Diakonia, https://www.diakonia.se/ en/. On its work in Palestine, see Diakonia, Israel and Palestine (oPt) [hereinafter Diakonia (2021)], https://www.diakonia.se/en/where-we-work/middle-east-north-africa/israel -and-palestine-opt/. I should declare that I worked as an independent consultant for Diakonia, writing the following: Ralph Wilde, Expert opinion on the applicability of human rights law to the Palestinian Territories with a specific focus on the respective responsibilities of Israel, as the extraterritorial state, and Palestine, as the territorial state, Diakonia (Feb. 2018), https://www.diakonia.se/ihl/download/download/applicability -human-rights-law-palestine-expert-opinion-wilde/ [hereinafter Wilde (2018)]. 
This is done through its "Diakonia International Humanitarian Law (IHL) Resource Centre." 29

As Hani Sayed observes, "the focus on the legality of the occupation [as a matter of IHL] is not politically neutral ... it implicitly incorporates a specific substantive position on the future of the Palestinian people and the nature of the political solution to the conflict." ${ }^{30}$ In occupation law, "occupation" denotes a situation where a state administers territory that is not its sovereign territory. ${ }^{31}$ Thus as a matter of law, deploying the terminology of the "Israeli

29 Diakonia (2021), above $\mathrm{n} 28$.

30 Sayed (2014), above n16, at 105-106 (fn omitted). The present article complements the analysis by Sayed, addressing different matters. See also 2014 Birzeit Conference, above nı.

31 On occupation law generally, see 1899 Hague Regulations and 1907 Hague Regulations, passim and especially Sections III, above n25; First Geneva Convention art. 2, above n24; Second Geneva Convention art. 2, above n24; Third Geneva Convention art. 2, above n24; Fourth Geneva Convention arts. 2, 27-34 \& 47-78, above n24. For academic commentary, see, e.g., the sources contained in the OUP Occupation list (2017), above n7; Adam Roberts, What is A Military Occupation?, 55 Brit. Y.B. Int' L. 249 (1985) [hereinafter Roberts (1985)]; Benvenisti (2012), above n22; Commentary on Geneva Convention (IV) Relative to the Protection of Civilian Persons in Times of War (J.S. Pictet ed., 1958); Gerhard Von Glahn, Law Among Nations: An Introduction to Public International Law Ch. 25 (7th ed., 1995) [hereinafter Von Glahn (1995)]; Arnold Wilson, The Laws of War in Occupied Territory, 18 Transactions Grotius Soc'y 17 (1932) [hereinafter Wilson (1932)]; Allan Gerson, Trustee-Occupant: The Legal Status of Israel's Presence in the West Bank, 14 Harvard Int'l L. J. 1 (1973) [hereinafter Gerson (1973)]; Hans-Peter Gasser, Protection of the Civilian Population, in The Handbook of Humanitarian Law in Armed Conflicts (Dieter Fleck ed., 1999); Adam Roberts, Prolonged Military Occupation: The Israeli-Occupied Territories Since 1967, 84 Am. J. Int'l L. 44 (1990) [hereinafter Roberts (1990)]; Scheffer (2003), above n22; Ardi Imseis, On the Fourth Geneva Convention and the Occupied Palestinian Territory, 44 Harvard Int'l L. J. 65 (2003) [hereinafter Imseis (2003)]; Nehal Bhuta, The Antinomies of Transformative Occupation, 16 Eur.J.Int'l L. 721 (2005); Roberts (2006), above n22; Valentina Azarova, Towards a Counter-Hegemonic Law of Occupation: On the Regulation of Predatory Interstate Acts in Contemporary International Law, 20 Y.B. Int'l Humanitarian L. Ch. 4, 113 (2017) [hereinafter Azarova (2017)]; Fionnuala Ní Aoláin, The Gender of Occupation, 45 Yale J. Int'l L. 338 (2020) [hereinafter Ní Aoláin (2020)]. As for the definition of occupation implying control over non-sovereign territory, this is implicit in the treaty definitions, which describe occupation as being "of the territory of a High Contracting Party" (i.e. of the territory of another party to the treaty other than the state engaged in the occupation). 1907 Hague Regulations art. 42, above n25; First Geneva Convention art. 2, above n24; Second Geneva Convention art. 2, above n24; Third Geneva Convention art. 2, above n24; Fourth Geneva Convention art. 2, above n24. Adam Roberts states that, "[a]t the heart of treaty provisions, court decisions and legal writings about occupations is the image of the armed forces of a state exercising some kind of domination or authority over inhabited territory outside the accepted international frontiers of their State and its dependencies." Roberts (1985), above, at 300. Eyal Benvenisti defines occupation as 
occupation" or the "occupied Palestinian territories" (oPt), or focusing exclusively on occupation law when it comes to the situation of Palestine and the Palestinian people, necessarily implies the following two elements. First, Israel is a state. Second, an exclusive focus on the land that is not the sovereign territory of Israel, and the people in that land, is to be adopted. The first element is essential. Occupation law only applies to states. ${ }^{32}$ Moreover, the concept of an occupation in this law presupposes a sovereign/non-sovereign distinction regarding the status of the occupying state and the occupied territory. Palestine is only "occupied," legally, if it falls outside the sovereign territory of Israel..$^{33}$

"effective control of a power (be it one or more states or an international organization, such as the United Nations) over a territory to which that power has no sovereign title." Benvenisti (2012), above n22, at 37. This non-sovereign-territory definition of occupation is presupposed by the prohibition on the annexation of territory through occupation (it is only relevant if occupied territory is not already the sovereign territory of the administering authority). This prohibition is addressed below, text accompanying n74 et seq. Equally, the prohibition on annexation is seen as the reason for the norms of occupation law, which, as discussed more below, are aimed at constraining the conduct of occupation in order to preserve the rights of the displaced sovereign over the territory in question. On this reason see below, text accompanying n49 et seq. Eyal Benvenisti states that " $[\mathrm{t}]$ he foundation upon which the entire law of occupation is based is the principle of inalienability of sovereignty through unilateral action of a foreign power, whether through the actual or threatened use of force ... Effective control by foreign military force can never bring about by itself a valid transfer of sovereignty." Put differently, it is because occupation cannot transfer sovereignty over the territory to the occupier, that "international law must regulate the inter-relationships between the occupying force ... and the local inhabitants for the duration of the occupation." Id., above n22, at 42. See also Roberts (2006), above n22, at $582-585$. The non-sovereign status of occupied territory is similarly presupposed by the conception of the relationship between occupier and occupied territory and population as one of "trust." On this, see the discussion below, text accompanying n174 et seq.

As far as occupation law presupposing that the actor engaged in the occupation is a state, this is because the relevant treaties, cited above n31, are only open to states as parties.

There is also the separate question of whether the treaty definition of occupation references to the territory of a "High Contracting Party" (see the treaty extracts above n31) limit the concept of occupation, and so the applicability of occupation law, to territory that falls under the sovereign territory of states who are contracting parties to the relevant treaties. This has potential implications for the Palestinian territories, bearing in mind their legal status. Most experts do not take the view that the legal definition of occupation has this limitation, the only issue, as far as the legal status of the territory in question is concerned, is whether or not it falls under the sovereign territory of the occupying state (and also, for some, whether or not it is inhabited by people, and whether it falls outside a state's colonial territories). See the general sources cited above $\mathrm{n} 31$; and, for examples 
As for the second element, the UN, most states, and independent experts of international law, generally follow the ceasefire "green line" from the 1967 war. This determines the boundaries between the sovereign territory of Israel and potentially occupied territory. ${ }^{34}$ Hence the focus on Gaza and the West Bank, meaning the territory of Mandatory Palestine from the west bank of the River Jordan to the green line. It therefore includes East Jerusalem, but otherwise stops at the borders of the state of Israel (West Jerusalem is a different matter, bearing in mind the "Corpus Separatum" issue). ${ }^{35}$ Within this framing, the question is what is "occupied" of this non-sovereign territory, i.e., what meets the legally required threshold of Israeli control triggering the application of occupation law. ${ }^{36}$ The standard view is that the threshold is certainly met in all of the West Bank. There is some debate about whether Gaza, post-"withdrawal," meets the threshold. ${ }^{37}$

Thus, the aforementioned exclusive focus on IHL generally, and occupation law in particular, has the following effect, as Hassan Jabareen, the Director of Adalah (the Legal Center for Arab Minority Rights in Israel), pointed out at

of this definition of occupation, see Imseis (2003), above n31, passim, and the quotations from Roberts (1985) and Benvenisti (2002), above n31.

34 On the legal status of the oPt, see, e.g., Roberts (1990), above n31; Imseis (2003), above n31; Imseis (2018/2022), above n16, passim; Erakat (2019), above n16, passim; Benjamin Rubin, Israel, Occupied Territories, Max Planck Encyc. Pub. Int'l L. (Oct. 20o9), https://opil .ouplaw.com/view/10.1093/law:epil/978019923169o/law-978o19923169o-e13o1.

35 For a review of the legal issues relating to the status of Jerusalem in general, see, e.g., Antonio Cassese, Legal Considerations on the International Status of Jerusalem, in The Human Dimension of International Law: Selected Papers of Antonio Cassese Ch. 12 (Antonio Cassese et al. eds., 2008) (and sources cited therein). It is also addressed in the sources cited above nı6. On East Jerusalem in particular, there is a question, beyond the scope of this article, as to whether or not Israel has purported to annex this territory, bearing in mind the extension of Israeli law to it (see Law and Administration Ordinance-Amendment No. 11 Law 5727-1967 (1967) (Isr.)); Municipalities Ordinance (Amendment No. 6) Law, 5727-1967, (1967) (Isr.)). On this question, see generally the aforementioned sources. For an example of the view that through the extension of its domestic law Israel has purported to annex East Jerusalem, see Orna Ben-Naftali, et al., Illegal occupation: framing the occupied Palestinian territory, 23 Berkeley J. Int'l L. 551, 573-574 (2005) [hereinafter Ben-Naftali et al. (2005)].

36 On the definition of occupation as far as the exercise of territorial control is concerned, see, generally, the sources cited above n31, in particular 1907 Hague Regulations arts. 42-43, above n25; First Geneva Convention art. 2, above n24; Second Geneva Convention art. 2, above n24; Third Geneva Convention art. 2, above n24; Fourth Geneva Convention art. 24, above n24; Roberts (1985), above n31, at 251-252, \& 300.

37 See, e.g., Iain Scobbie, Gaza, in International Law and the Classification of Conflicts 295 (Elizabeth Wilmshurst ed., 2012) (and sources cited therein). 
the Al-Haq conference, and I am paraphrasing: it excludes crucial elements of the Palestinian struggle - the Nakba, the position of Palestinian people in the land between the river and the sea outside the West Bank and Gaza, and the refugees. ${ }^{38}$ Accordingly, the focus in the case of the Jahalin is only on the situation in the West Bank, including efforts to forcibly relocate them to near the garbage dump in Abu Dis. The original displacement from al-Naqab is off the table. Amran Reshaq's wish to return is ignored.

The Palestinian struggle is legally framed in a way that excludes these aspects of it. What is claimed to be a humanitarian effort to vindicate the needs of Palestinian people in the oPt erases the struggle as it relates to all other Palestinian people, both on the other side of the green line from the oPt, and beyond. ${ }^{39}$ It also ignores the Palestinian people in the oPt insofar as their links, including of land and property, with the other side of the green line are concerned, as in the case of the Jahalin. Put differently, the exclusive focus on the IHL/occupation framework denies, through omission, the right of return and the rights of Palestinian people on the other side of the green line from the oPt to equal treatment as citizens of Israel. More fundamentally, this framing excludes any questioning of the "green line" as an organizing principle for the question of the status of the land between the river and the sea and the people who have a relationship to it. Because occupation law's applicability presupposes Israeli statehood, invoking it as a regulatory framework effectively takes a position on this more fundamental matter, and what follows, that the horizons for Palestinian liberation are limited to the West Bank and Gaza. What is on its own terms only concerned with how Israel treats the Palestinian people in these territories has direct implications for more fundamental matters such as the one state/two state "solution."40

38 Confirmed in an email from the speaker, on file with the author and this Yearbook. See also Hassan Jabareen, How the Law of Return Creates One Legal Order in Palestine, 21 Theoretical Inquiries L. 459 (2020). On these issues and the areas of international law relevant to them, see, e.g., and the sources cited therein, Yahia (1970), above n16, at 106-115 (on the Nakba and the refugees), at ${ }^{115}-124$ (on Palestinian people within Israel); Imseis (2018/2022), above n16; Erakat (2019), above n16; and, on the refugees in particular, Francesca Albanese \& Lex Takkenberg, Palestinian Refugees in International Law (2nd ed., 2020) [hereinafter Albanese \& Takkenberg (2020)]. See also below, text accompanying $\mathrm{n} 215$ et seq.

39 On these themes, see also Darryl Li, Occupation Law and the One-State Reality, Jadaliyya (Aug. 2, 2011) [hereinafter Li (2011)], https://www.jadaliyya.com/Details/24275/Occupation -Law-and-the-One-State-Reality.

40 On further aspects of the problematic nature of starting in 1967 , and "the exclusion of 1948," see the critique in: Nimer Sultany, International Law's Indeterminacy and 1948 
Thus an Amnesty International UK webpage on the Palestinian situation asks readers to "HELP END THE 5 O YEAR OPPRESSION OF PALESTINIANS." It boasts that "When we see people suffering, we don't back down - we act." This action is described as "campaigning hard to end the human rights abuses suffered by Palestinians under the Israeli occupation for the last 50 years." 43 Such a timeframe and related exclusive focus on the "occupation" ignores or necessarily assumes as settled all that happened prior to 1967 . Moreover, it limits the focus from the entire land from the river to the sea to whatever was left of this land after the creation of Israel in 1948. It reflects how, as Samera Esmeir observed at the Muwatin conference, "the project of human rights has configured the horizons of political and ethical possibilities under conditions of colonial destruction, [and] has charted new itineraries for political life by diminishing the pursuit of collective freedom adequate to a non-colonial future."44 In its general statement about IHRL forming the "bedrock" of all Amnesty International campaigning, Amnesty International UK insists on the relevance of the UDHR as an instrument to guide Amnesty International's work despite the long passage of time ("although it is now over 6o years old this document remains fundamental to our work"). ${ }^{45}$ However, it is not prepared to adopt a similar time span - indeed, the same time span, since the beginning of the Nakba and the creation of Israel, on the one hand, and the adoption of the UDHR, on the other hand, happened in the same year - when then it conducts this work in relation to Israel and Palestine.

Moreover, even within the distorted focus exclusively on the occupation and the territory and people covered by that, the exclusive IHL/occupation law approach is only concerned with the "humanitarian" conditions in the oPt. As will be explained, the occupation itself is not placed into question. Whereas Israel's position as a state has been affirmed, Israel's right to control the oPt has not been questioned. Occupation law, then, requires Palestinian people to affirm Israeli statehood in order to invoke a regulatory regime that

Palestine: two comments on Aeyal Gross's The Writing on the Wall, 6 London Rev. Int'l L. 315, 320-324 (2018).

41 Amnesty International UK (2019), above nıo (emphasis in original).

42 Id.

43 Id.

44 Samera Esmeir, paper presented at the Muwatin conference (unpublished), on file with the author.

45 Amnesty International UK (2018), above ng. This statement could be found on the website at the time of writing, 2021, which is, of course, more than 70 years since the UDHR was adopted (the Muwatin conference commemorated the 7oth anniversary). 
is not concerned with the corresponding question of their own right to collective freedom.

IHL, including occupation law, regulates war/occupation when it happens. ${ }^{46}$ It does not also challenge the legitimacy of occupation itself - whether it should be in existence. It is presumably for this reason that at the Al-Haq conference, Munir Nusseibeih of Al Quds University said, to paraphrase: occupation is not illegal, it is simply regulated by international law. ${ }^{47}$

Some have tried to challenge this by arguing that the law of occupation rules out a "prolonged occupation." ${ }^{48}$ This argument proceeds as follows. Occupation law addresses a situation after war, when a victorious state ends up in control of the defeated state's territory. ${ }^{49}$ The situation has to be regulated, it is said, to ensure that the rights of the temporarily displaced sovereign are preserved..$^{50} \mathrm{~A}$ regime is introduced to preserve the status quo and provide basic guarantees, until the displaced sovereign returns, and the occupation ends. All of this assumes it is a temporary situation. ${ }^{51}$ Some take the existence of this assumption to conclude that, given that a prolonged occupation would operate contrary to it, such an occupation would be illegal in occupation law. ${ }^{52}$

However, just because those who sought to regulate occupations saw such occupations as temporary does not mean that the temporary nature of occupations is thereby rendered legally obligatory by that regulatory framework. This is a non sequitur, transforming a regulatory regime only concerned with the operation of occupations into one that also addresses the existential matter of whether occupations should be in existence. The requirement that an occupation be temporary arises out of the entitlements of the displaced sovereign in general international law to resume control of its territory, and the limits of the

$46 \quad$ See the sources cited above $n_{7} \& n_{31}$.

47 Confirmed in an email from the speaker, on file with the author and this Yearbook. See also the reported comments by Allegra Pacheco, in: 2014 Birzeit Conference, above nı6.

48 See, e.g., in the context of the oPt, Ben-Naftali et al. (2005), above n35. But see below when it comes to their proposal for how the Israeli occupation might end, text accompanying ni59.

49 See the sources cited above $\mathrm{n}_{7} \& \mathrm{n}_{3}$. For a discussion about this aspect, see, e.g., BenNaftali et al. (2005), above n35, at 592 et seq.

50 Id.

$5^{1}$ Id. In the words of Benvenisti: "Because occupation does not amount to sovereignty, the occupation is also limited in time and the occupant has only temporary managerial powers, for the period until a peaceful solution is reached. During that limited period, the occupant administers the territory on behalf of the sovereign." Benvenisti (2012), above n22, at 6. On temporariness, see also Ben-Naftali et al. (2005), above n35; Salvatore Nicolosi, The Law of Military Occupation and the Role of De Jure and De Facto Sovereignty, 31 Polish Y.B. Int'l L. 165 (2011).

$5^{2}$ This is seemingly the argument put forward by Ben-Naftali et al. (2005), above n35. 
belligerent occupant's right to prevent this, which are determined by a test set by the international law on the use of force - the jus ad bellum. These normative considerations will be returned to in the next two sections. Treating the in bello regime of occupation law as if it had ad bellum characteristics in this way is to make a category error.

But might, at least, the full implementation of IHL including occupation law remove any benefits to an occupier derived from continuing the occupation?53 So, for example, in the case of Palestine, what if the settlements were removed, there was proper freedom of movement for Palestinian people, the end of resource exploitation etc. ${ }^{54}$ Would this eliminate the advantages Israel gained from the occupation? In particular, Israel would no longer be able to create "facts on the ground" to assist it in successfully asserting/acquiring sovereignty over parts of the West Bank. Israel would also be prevented from doing things understood to constitute the de facto exercise of sovereignty (annexation is addressed in the next section). It might be suggested that although occupation law does not directly require an occupation to end, the things it does require directly of the occupying state might have an indirect effect in removing the advantages, for sovereignty-asserting/annexationist ambitions, gained through maintaining the occupation. If so, when it comes to how occupation law does or does not address the existential legitimacy of the occupation, the issue might be not only whether this is covered by some sort of implied rule based on the temporary nature of occupations. It might also be a matter of the constructive effect of the obligations being fully complied with.

The significance of compliance in this regard is potentially illustrated by the occupation of Iraq. There, the CPA, through which the US and the UK conducted the occupation, aimed at the economic, political and legal transformation of the country - "transformatory occupation." ${ }^{55}$ Key changes would be made, notably concerning how natural resources would be exploited and owned. Administrative authority would then be transferred to the Iraqi people. The US and the UK separately, and as part of the UN Security Council

53 I am grateful to Anna Mykytenko of the NGO Global Rights Compliance, based in Ukraine (the subject of another occupation, that of Crimea by Russia) who raised this point and discussed it with me at the Al-Haq conference.

54 On the rules of occupation law relevant to these practices, see, generally, n31; and, on the settlements in particular, see Fourth Geneva Convention art. 49, above n24; and, as far as violations concerning settlements constituting war crimes, see Rome Statute of the International Criminal Court art. 8.2.b.viii, July 1, 2002, 2187 U.N.T.S. 3, as amended (through resolution RC/Res.6 of June 11, 2010) [hereinafter Rome Statute].

55 On the occupation of Iraq generally, including commentators who use the "transformatory occupation" term, see the sources cited above n22. 
(UNSC), acknowledged that this was an occupation, thereby accepting that occupation law applied to it. ${ }^{56}$ Some legal experts working for those states, and some academic commentators, identified this law as an impediment to the intended changes, given its general "preserving the status quo" orientation. ${ }^{57}$ It was argued that there was a need to move "beyond occupation law."58 They expressed concern that if this law was followed, the changes would not be possible. ${ }^{59}$ The objective served by maintaining the occupation beyond a short period necessary to transfer power to the Iraqi people - to profoundly alter the economic and political character of the state - would be legally impermissible. We might see in these arguments compliance with occupation law being understood as significant to the existential question of the duration and termination of an occupation.

As two (permanent) members of the UNSC, the US and the UK were able to work within that body to pass resolutions that supposedly gave them the authority to engage in the transformation of Iraq. ${ }^{60}$ This process was, moreover, discussed as potentially, through the operation of the trumping norm in UN Charter article 103, somehow modifying any inconsistent norms of occupation law. ${ }^{61}$ There is much that could be said about what was intended in and/or what the legal effects of this process were. ${ }^{62}$ For present purposes, the example is given to illustrate how occupation law can be viewed as an impediment to doing the sorts of things that would have necessitated prolonging that occupation. ${ }^{63}$

However, the crucial difference between the occupation of Iraq, and the Israeli occupation of the Palestinian territories, is that the US and the UK did not aspire to formally incorporate Iraqi territory into their sovereign territory. They wanted to transform its economic and political system only. Without an ability to do this, there would have been little purpose served by maintaining control beyond the time it took to temporarily fill the vacuum in

56 See S.C. Res. 1483 (May 22, 2003), pmbl., referencing the US and UK as "occupying powers" and being in receipt of a letter from these states acknowledging this.

57 See, e.g., Scheffer (2003), above n22.

58 Id.

59 On the broader question of what is permitted by way of transformation under occupation law, see the sources cited above n31; and, in particular, Benvenisti (2012), above n22, Ch. 4; Roberts (1985), above n31.

$60 \quad$ See, e.g., S.C. Res. 1483 (2003), above 5 56, op cit.

61 See, e.g., the authorities cited above nz2.

$62 \quad I d$.

63 Whether it actually has this effect is a subject of debate. On this, see, e.g., the sources cited above n22 \& $\mathrm{n} 31$. 
governance created by their removal of Saddam Hussein, before handing over to local representatives.

When, however, a state has sovereignty-related ambitions, as with Israel, Morocco (in Western Sahara), Russia (in Crimea), and, in the period between 1975 and 1999, Indonesia (in East Timor), the situation is different. ${ }^{64}$ Full compliance with occupation law would remove the ability to alter facts on the ground in order to support these ambitions, e.g. implanting settlements. But there would still be a purpose served in maintaining the occupation itself "facts on the ground" in a more elemental sense - for leverage purposes to gain an advantage when the question of sovereignty was being addressed. Similarly, insofar as ensuring security for Israel is a factor, maintaining an occupation even when complying fully with occupation law serves a purpose..$^{65}$

Here, the contrast with Gaza is instructive. Israel withdrew its "boots on the ground" presence because it did not want the territory and could maintain its security through the siege and control exercised by air, sea, and at the borders. ${ }^{66}$ The West Bank is the subject of territorial sovereignty assertions/ aspirations and is understood to pose a different security proposition. ${ }^{67}$

It is not possible, therefore, to place faith in the notion that full compliance with occupation law would somehow necessarily end the conditions that incentivize Israel to maintain the occupation in order to further its sovereigntyrelated aspirations.

Indeed, treating the situation as one of "occupation" governed by occupation law can be advantageous to Israel, given that its sovereignty aspirations relating to the West Bank have to reckon with the existence of the Palestinian population there. ${ }^{68} \mathrm{~A}$ formal annexation of the entire West Bank would necessarily raise the question of granting those people Israeli citizenship. Doing this would place the sustainability of the majority-Jewish character of Israel

64 On Morocco and Western Sahara, see the sources cited above nı. On Russia and Crimea, see the source cited above n21. On Indonesia and East Timor, see the sources cited above n2o.

65 In Iraq, the US and UK pursued their security objectives through a continued military presence after handing over formal administrative control to local representatives. "Consent" for this presence was supposedly provided by those representatives, whose position as such owed much to what happened during the formally proclaimed occupation period. The continued presence may actually have constituted occupation either generally or in parts of the country. See, e.g., S.C. Res. 1546 (June 8, 2004), passim; and more broadly the commentary above n22.

66 On this, see the source cited above $\mathrm{n} 37$ (and further citations contained therein).

67 Annexation is addressed in the following section.

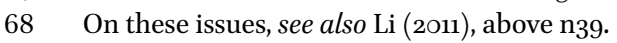


under strain. The alternative would be to conduct mass forcible expulsions, as in 1948; or to treat the people as second-class persons without citizenship, i.e. an apartheid regime, as in Israel's treatment of Palestinian people in (potentially purportedly annexed) East Jerusalem. ${ }^{69}$ In contrast, treating the situation as an occupation (outside East Jerusalem, if Israel has purported to annex that area) enables Israel's exercise of control over an inhabited territory to avoid these challenging alternatives. It provides a patina of basic protections to the subordinated population and "humanizes" this subordination without affording equal rights. Israel can then benefit from the "facts on the ground" advantage for its sovereignty claims that such control provides. It could pave the way for "land for peace" swaps involving the depopulation of some of this territory of its Palestinian population and the conferral of Israeli sovereignty over that territory.

To address the existential question of bringing occupations to an end, it is necessary to depart from occupation law; ${ }^{70}$ to go "beyond" it, as certain commentators wanted to do in Iraq. But not, as in that case, to enable a different, "transformatory" occupation. Rather, to be able to make arguments that would transform the situation triggering the application of occupation law - the occupation itself - to one of liberation. Sticking only to the frame of reference covered by occupation law necessarily means addressing only how "humanitarian" occupations are. It is not possible to address whether and when they should end. The debate is only about the merits and legality of "transformatory" occupation. It is not a discussion about whether occupation itself can be "transformed" out of existence.

69 On apartheid, see below ni13. On the question of whether Israel has purported to annex East Jerusalem, see above $\mathrm{n}_{35}$.

70 See also Azarova 2017, above n31. Hani Sayed also argues that there are other reasons why the focus on occupation/occupation law is a distraction, rooted in the problematic way it characterizes the situation faced by the Palestinian people in their relations with Israel. Sayed (2014), above n16. At the end of his piece, Sayed states: "The challenge is ultimately to imagine a legal framework for understanding the situation in the WBGS [West Bank and Gaza Strip] that does not link the Palestinian right to self-determination to the law of occupation." Id., at 148-149. For different, complementary reasons, I am also arguing herein about the problems of linking the self-determination of the Palestinian people to the law of occupation. But also, more broadly, I am suggesting some of the problems in seeking to approach self-determination through any legal framework, insofar as the options for such a framework are those that exist within international law as currently conceived. And, relatedly, I am concerned with some of the problems with the focus only on the "WBGS" when it comes to the question of the self-determination of the Palestinian people. For additional analysis on further problems with the focus on IHL, and on law generally, see Reynolds (2015), above ni6. 
Two areas of international law do, it is claimed, speak to the existential legitimacy of the occupation in the oPt: the law on the use of armed force and self-determination. The following sections address each in turn.

\section{Law on the Use of Force, Including Its Interface with the Law on Title to Territory}

The existential legitimacy of war, including the conduct of associated military occupation, is the subject of the "law on the use of force" - the jus ad bellum. ${ }^{71}$ Israel's presence in the oPt stems from the $1967 \mathrm{war}$, and is, therefore, a "belligerent" occupation and falls to be determined, as a use of force, under this legal framework. ${ }^{72}$ Legality depends on two factors. In the first place, (a), is whether there is a legally-acceptable "just cause," defined as the existence of particular type of threat and/or use of force necessitating a defensive response involving the threat/use of force. ${ }^{73}$ In the second place, (b), is whether the defensive response taken is a necessary and proportionate means of responding to that threat/use of force. Before turning to this as a general matter, it is necessary to addresses the related question of the legitimacy of that which the occupation is commonly associated, as reflected in the title of the Al-Haq conference: annexation of all or part of the oPt.

Annexation - the acquisition of title over territory whether or not that territory is the sovereign territory of another state - is not a legally-acceptable "just cause" under (a). ${ }^{74}$ Thus, the use of force - including an occupation - for this purpose is illegal ab initio. Relatedly, the use of force cannot by itself be the

71 On the law on the use of force, see Michael Wood, Use of Force, Prohibition of Threat, Max Planck Encyc. Pub. Int'l L. (June 2013) (and sources cited therein), https://opil .ouplaw.com/view/10.1093/law:epil/978o19923169o/law-978o19923169o-e428; OUP UoF list (2020), above n6; Christine D. Gray, International Law and the Use of Force (4th ed., 2018) [hereinafter Gray (2018)] (and sources cited therein).

72 See the sources cited above n31 \& $n_{34}$.

73 Note the emphasis here is on "legally-acceptable" in order not to confuse this requirement with what might be understood to be justified through a (potentially broader) non-legal "just war" theory.

74 Because it is absent from the permitted bases for using force and is, indeed, embedded in the prohibition on the use of force ( $c f$. the reference to "territorial integrity" in UN Charter art. 2(4)). See the sources cited in: OUP UoF list (2020), above n6; and, in particular, Sharon Korman, The Right of Conquest: The Acquisition of Territory by Force in International Law and Practice (1996) [hereinafter Korman (1996)]; and below, the following note. 
basis for the acquisition of territory (again, whether or not that territory is the sovereign territory of another state), what is referred to as "conquest" or "subjugation" under the law of title to territory. In the words of the UNSC, it is "inadmissible," i.e., any claim to title over territory made on this basis is invalid. ${ }^{75}$

75 See, e.g., the following statements made by the UNSC in the particular context of the oPt: "inadmissibility of the acquisition of territory by war" (S.C. Res. 242 (Nov. 22, 1967), pmbl.); the "acquisition of territory by military conquest is inadmissible" (S.C. Res. 298 (Sep. 25, 1971), pmbl.); the "acquisition of territory by force is inadmissible" (S.C. Res. 476 (June 3 o, 1980), pmbl.); the "inadmissibility of the acquisition of territory by force" (S.C. Res. 2334 (Dec. 23, 2016), pmbl.). The Friendly Relations and Co-operation Declaration of the UNGA asserted that "no territorial acquisition resulting from the threat or use of force shall be recognized as legal". G.A. Res. ${ }_{2625}(\mathrm{XXV})$, Declaration on Principles of International Law concerning Friendly Relations and Co-operation among States in accordance with the Charter of the United Nations (Oct. 24, 1970). This statement was affirmed in the context of the Israeli occupation of the Palestinian Territories in the Wall Advisory Opinion, where the ICJ describes it as a "corollary" to the "principles as to the use of force," "entailing the illegality of territorial acquisition resulting from the threat or use of force." Legal Consequences of the Construction of a Wall in the Occupied Palestinian Territories, Advisory Opinion, 2004 I.C.J. Rep 136 (July 9), para. 87 [hereinafter ICJ Wall Advisory Opinion]. Article 4 of the CSCE Helsinki Final Act proclaimed that "the participating States will ... refrain from making each other's territory ... the object of acquisition by means of [occupation]. No such ... acquisition will be recognized as legal." Conference on Security and Co-operation in Europe, Helsinki Final Act, Aug. 21, 1975, 14 I.L.M. 1292, 12941295 [hereinafter Helsinki Final Act]. For academic authority, see, e.g., Robert Y. Jennings, The Acquisition of Territory in International Law (1963/2017), 2017 reprint, section IV, at 68-85 [hereinafter Jennings (1963/2017)]; W. Schätzel, Die Annexation im Völkerrecht, 2 Archiv des Völkerrechts 1 (1949); Hoffman (2020), above nı9; Roberts (2006), above n22, at $582-585$; Korman (1996), above $\mathrm{n} 74$. For academic authority specifically on annexation and the West Bank, see Open Letter to the Israeli Government Condemning Annexation by International Law Scholars, Opinio Juris (June 11, 2020) [hereinafter Annexation Letter (2020)], http://opiniojuris.org/2020/o6/11/an-open-letter-to-the-israeli-government-con demning-annexation/. For Robbie Jennings, because of the legal prohibition on the use of force, "it seems impossible ... to concede that the successful seizure of another's territory by force, i.e. conquest, or subjugation, may be itself a lawful title to the territory." Jennings (1963/2017), at 84. In the words of Masaharu Yanagihara, "conquest is incompatible with the prohibition of the use of force in international relations." OUP Territorial Title list (2016), above n6. Eyal Benvenisti describes the position as "the principle of inalienability of sovereignty through unilateral action of a foreign power, whether through the actual or threatened use of force ... Effective control by foreign military force can never bring about by itself a valid transfer of sovereignty." Benvenisti, above n22, at 42 . See also, id., at 169. As indicated by the language of "another's territory," "conquest," and "sovereignty" used by Jennings, Yanagihara, and Benvenisti, the implication of these positions on the non-forcible-annexation of title to territory is that the territory in question is either the sovereign territory of another state (or more than one state), or a non-state territory that is not terra nullius and so where the rights of the local population to self-determination would be a bar. This is addressed further below, text accompanying n138. In the law of title to territory, the term "occupation" is used to denote a head of title based on effective 
This is the case even if the use of force/occupation might be lawful as a matter of the law of self-defense (to be addressed further below). ${ }^{76}$

Thus, the designation of the Palestinian Territories as "occupied" has two cumulative effects. Impliedly, the territories are not the sovereign territory of Israel. Consequently, the law on the use of force prevents Israel from founding a legally valid claim to sovereignty based on the control exercised over the territories. Moreover, it prohibits Israel from conducting the occupation on the basis of founding such a claim. Put more simply, an assertion of annexation based on the occupation would be both illegal (as a prohibited use of force) and without legal effect, as far as territorial acquisition is concerned. (It is important to acknowledge that this presupposes that the territories do not form part of territory which Israel either enjoys or somehow has the right to enjoy title over. Annexation is a matter of forming a new root to title, not asserting control over territory in relation to which the state already has or is entitled to title). ${ }^{77}$

As with occupation law, this legal position on annexation presupposes that the relevant areas of international law - the law on the use of force, and the law on title to territory - apply to Israel as a state. To make these arguments about the illegality of annexation is to presuppose Israeli statehood and the "green line" framework. Necessarily, the exclusive focus on Israel annexing new territory is not concerned with other matters such as Palestinian return to the land that since 1948 has been in the territory of Israel. For the Jahalin, then, Israel is prevented from annexing the land on which Khan Al-Ahmar is located (e.g. as part of a broader move encompassing the surrounding settlements). Amran Reshaq's concern to return to al-Naqab is not addressed.

control of terra nullius. See. e.g., Jennings (1962/2017), above $\mathrm{n}_{75}$, at $33^{-37}$. The significance of this is addressed below, text accompanying n138.

76 Jennings (1963/2017), above $n 75$, at $71-72$. In the words of Christine Gray, "the use of force in self-defence has not been accepted as a valid root of title to territory." Gray (2018), at 164 (citing Jennings (1963/2017), the 1963 publication, at 203 (in the 2017 reprint, the book only has 16o pages - the relevant pages on this point are cited at the start of this note); Korman (1996), above n74; Allan Gerson, Israel, The West Bank And International Law (1978) [hereinafter Gerson (1978)].

77 In the words of Robbie Jennings, "although closely linked ... title and the use of illegal force are distinct questions ... the putative aggressor may be in fact the one who is entitled;" Jennings (1963/2017), above $\mathrm{n} 75$, at 85 . See also, id., at 82-84. Thus, to apply this framework it is necessary, for example, to have rejected the notion that, via the Balfour Declaration and the League of Nations Mandate Agreement for Palestine the entire territory of Mandatory Palestine (so including the oPt) was somehow determined to be allocated to the future state of Israel, and that this determination was internationally-legallyeffective, and in operation with such legal status on and after 1967. 
Robbie Jennings, a canonical authority on this area of international law, once posed the following question in relation to a situation where a state retains control over territory captured in war: "is there any point in denying title to the thief if there is little hope of being able to deny him the thing itself?."78 Jennings posed this question to highlight the problem of the lack of enforcement of the prohibition of force-enabled annexation. This is clearly relevant to the Israel-Palestine situation. That said, his question, as befits the context of a study of title to territory, discusses only title as that which could determine the legitimacy of the control exercised over the "thing." However, there is an alternative potential basis for such legitimacy, which, moreover, presupposes that the territory is indeed not the sovereign territory of the state concerned. This covers all of the West Bank, not just the part(s) that Israel may have purported to annex. It is the right of self-defense. ${ }^{79}$ Even if Israel cannot annex all or part of the West Bank through the occupation (which would transform legally the legitimacy of Israel's control to that conducted by a state within its own territory), this is not by itself necessarily dispositive of the legality of Israel's exercise of control there.

Self-defense has been a justification for the occupation put forward by Israel. ${ }^{80}$ However, commentary on the legality of the occupation tends to ignore the relevance of the law on the use of force (other than as far as annexation is concerned). ${ }^{81}$ Or, to invoke this area of law, only to then dismiss its relevance (other than to annexation). ${ }^{82} \mathrm{Or}$, to address the occupation's legality in these terms in a cursory fashion. ${ }^{83}$

$78 \quad$ Id., $76-77$.

79 Or authorization by the UNSC, which is not relevant to the occupation of Palestine. The potential significance of UNSC Resolution 242 is addressed below nıo. On UNSC-authorized force, see the sources contained in OUP UoF list (2020), above n6. On the link between lawful use of force and occupation, see, e.g., Stephen M. Schwebel, What Weight to Conquest?, 64 Am. J. Int'l L. 344 (1970) [hereinafter Schwebel (1970)]. On the subject of the self-defense right and the occupation, see, e.g., sources in the following fns, and Yahia (1970), above n16, at 147-77 \& 184; John Quigley, The Oslo Accords: International Law and the Israeli-Palestinian Peace Agreements, 25 Suffolk Transnat'l L. Rev. 73, 81 (2001); Imseis (2020), above n16, at 1073 (and sources cited therein).

8o On Israel invoking self-defense to justify the occupation, see, e.g., Antonio Cassese, SelfDetermination of Peoples: A Legal Reappraisal 235 (1995) [hereinafter Cassese (1995)] (and sources cited therein).

81 See, e.g., 2014 Birzeit Conference; and Reynolds (2015), both above n16.

82 See, e.g., Ben-Naftali et al. (2005), above $\mathrm{n} 35$, in particular at 559, 573, \& 613 .

83 See, e.g., Yael Ronen, Illegal Occupation and its Consequences, 41 Isr. L. Rev. 201, 242 (2008) (Ronen 2008) ("With respect to Israel, there is at least a credible claim that the occupation was a result of lawful action in self-defense"). A notable exception to the foregoing approaches is Azarova (2017), above n31. 
It is helpful to divide the occupation into two phases. The first phase covers the existence of a threat giving rise to a legally valid right to self-defense (issue (a)) existing when the occupation commenced in 1967. If not in existence, then the occupation was unlawful $a b$ initio because of a legally invalid casus bellum. ${ }^{84}$ If in existence, this had to justify, as necessary and proportionate, introducing plenary military occupation of the entire West Bank (issue (b))..$^{85}$ If the occupation was unnecessary and disproportionate, then (again) it was unlawful ab initio. The second phase covers the period after the initial introduction of the occupation to today. For the occupation to be lawful during this second, 5o-plus year phase, the original threat, and/ or another threat also falling within the boundaries of that which justifies recourse to force in self-defense (again, issue (a)), has to be in operation. ${ }^{86}$ If this is the

84 Thus, the UNGA, having defined aggression, explains the types of acts that can qualify for this if they meet the definition, and includes " $[\mathrm{t}]$ he invasion or attack by the armed forces of a State of the territory of another State, or any military occupation, however temporary, resulting from such invasion or attack." G.A. Res. 3314 (XXIX), Definition of Aggression (Dec. 14, 1974), art. 3(a). This formulation was adopted when aggression was eventually defined for the purposes of the crime of aggression under the Rome Statute for the ICC. See Rome Statute art. 8 bis, para. 2(a), above $\mathrm{n}_{54}$. The Helsinki Final Act art. 4 proclaimed that " $[t]$ he participating States will refrain from making each other's territory the object of military occupation or other direct or indirect measures of force in contravention of international law.... No such occupation ... will be recognized as legal," Helsinki Final Act, above $\mathrm{n} 75$. Eyal Benvenisti characterizes the occupations by the Axis powers before and during so-called World War II as illegal "predicated on the aggression" (i.e. illegal use of force) "that led to the occupation," Benvenisti (2012), above n22, at 140. Reviewing the changes in international law on the use of force, Benvenisti observes that "the outlawing of war rendered illegal the occupation that resulted from an act of aggression." Id., at 167-168 (fn omitted referencing the foregoing definition of aggression and proclamation from the Helsinki Final Act).

85 So, for example, in the context of the occupation, writing in 1970 Steven Schwebel observes: "A state acting in lawful exercise of its right of self-defense may seize and occupy foreign territory as long as such seizure and occupation are necessary to its self-defense." Schwebel (1970), above n79, at 345 (emphasis added). But see what is covered below when it comes to the test Schwebel articulates in the context of a continued occupation, below n95. As is sometimes evident in analysis on the use of force generally, some commentators miss this second stage of the analysis, focusing only on the legally-permissible "just cause" element. See e.g., Michael Curtis, International Law and the Territories, 32 Harvard Int'l L. J. 457, 464 (1991) [hereinafter Curtis (1991)].

86 There is a debate as to whether and to what extent Israel has a right of self-defense in relation to threats emanating from the Palestinian territories, bearing in mind the legal status of those territories, and the non-state character (if that is indeed correct) of the actors in them Israel claims poses the threat. This debate came to prominence with the dicta of the ICJ in the Wall Advisory Opinion which potentially had implications for it. See ICJ Wall Advisory Opinion, above n75, para. 139; id., separate opinions of Judge Buergenthal (para. 6), Judge Higgins (paras. 33-35), and Judge Kooijmans (para. 35). The 
case, the plenary occupation has to be a necessary and proportionate response to this threat/these threats. Moreover, both these requirements (the threat, and the necessity of the occupation as a response) need to be evident in a continuous, unbroken state for the entire period.

International law experts, and most states, tend to regard as implausible the idea that prolonged occupations, such as those covering the second phase, can ever be justified according to this framework. Including, notably, when it comes to the requirements of necessity and proportionality. Christine Gray, for example, reports that " $[\mathrm{n}]$ ecessity and proportionality are ... crucial in the rejection by states of the legality of prolonged occupation of territory in the name of self-defence." ${ }^{\prime 87}$

Indeed, it is not credible to regard the occupation as a necessary and proportionate means of ensuring Israel's security, as far as the legitimate imperatives of security are concerned and how they are accounted for in the legal test. These imperatives could be achieved through considerably less extreme measures. ${ }^{88}$ Securing them through occupation is excessive, and therefore unnecessary. Thus, the second phase of the occupation, from its introduction to today, has been and is unlawful under the law on the use of force. ${ }^{89}$ As such, it meets the definition of aggression. ${ }^{90}$ Notably, the UN General Assembly (UNGA) has frequently condemned the continued occupation as a violation of the UN Charter and the principles of international law. ${ }^{91}$

issue of whether there is a right of self-defense against non-state actors is of broader relevance and was similarly prominent contemporaneously to the ICJ's pronouncement in the Wall Advisory Opinion in the context of the military action taken by the US against Al Qaeda as part of the "war on terror" following the attacks on the US in 2001. These issues are beyond the scope of the present article (for a discussion of them see the sources in OUP UoF list (2020), above $n 6$ ). For the sake of addressing all potential justifications Israel might have to maintain the occupation based on the right of self-defense, the present analysis assumes that such a right could arise in the context of threats from non-state actors emanating from occupied territory.

87 Gray (2018), above $\mathrm{n} 71$, at 164 . See also the quotation from S.C. Res. 476, below niol, and the observations by Cassese quoted below, text accompanying nı43.

88 On the relevant legal framework, see sources contained in the OUP UoF list (2020), above n6. For an application to this situation reaching the same conclusion, see, e.g., Richard Falk \& Burns Weston, The Relevance of International Law to Israeli and Palestinian Rights in the West Bank and Gaza 32 Harvard Int'l L. J. 129, 148-149 (1991).

89 Quite apart from whether or not the first phase was or was not lawful; on which, see the sources cited above $\mathrm{n} 79$.

9o On an unlawful occupation in use of force terms constituting aggression, see the sources cited above $\mathrm{n} 6, \mathrm{n} 71$ \& $\mathrm{n} 84$. On the link to the individual crime of aggression, see Rome Statute art. 8 bis, para. 1, above $\mathrm{n}_{54}$, and below nıo9.

91 See the review and citations in Imseis (2020), above n16, at 1069-1070. Note also quotation from S.C. Res. 476, below nıo1. 
It is sometimes suggested that an occupation that was initially lawful as a means of self-defense can somehow then remain lawful pending the adoption of peace settlement/agreement. ${ }^{92}$ Certain commentators even suggest that the occupation can be maintained until an agreement is adopted which goes beyond the specific defensive needs justifying it originally, encompassing the more general security needs of the occupying state, and/or broader matters that have security and other important implications, such as delimiting disputed borders. ${ }^{93}$ These approaches are sometimes linked to a doctrine of justifying the use of force pre-emptively, not to deal with an actual/imminent/ ongoing threat but, rather, to prevent such a threat from arising. ${ }^{94}$ This doctrine enables Israel to maintain control until an agreement provides an alternative means of preventing future threats. ${ }^{95}$

In his treatment of the oPt, in a section entitled "Is there an obligation to end the occupation?" Eyal Benvenisti asks

Does the occupant have the right to retain control over the occupied territory until its conditions for a peaceful arrangement are met? Does it have a duty to relinquish control under certain circumstances? Ultimately, the question is, upon whom does the burden of breaking political stalemate lie when negotiations for peace fail? ${ }^{96}$

92 Writing in 1970 about the occupation of the Palestinian territories, Rosalyn Higgins states: "there is nothing in either the Charter or general international law which leads one to suppose that military occupation, pending a peace treaty, is illegal. The Allies, it will be recalled, did not claim title to Berlin in 1945; but neither did they withdraw immediately [after] they had entered it." Rosalyn Higgins, The Place of International Law in the Settlement of Disputes by the Security Council, 64 Am. J. Int'l L. 8 (1970), reproduced in Rosalyn Higgins, Themes and Theories 181 (2009) (of the reproduced version). Meir Shamgar stated that "pending an alternative political or military solution [occupation] ... could, from a legal point of view, continue indefinitely." Meir Shamgar, Legal Concepts and Problems of the Israeli Military Government - The Initial Stage, in Military Government in the Territories Administrated by Israel 1967-1980 43 (Meir Shamgar ed., 1982). See also Schwebel (1970), above n79, at 344-346 (discussed further below, n95, nıo1, \& n1o3).

93 See, e.g., Curtis (1991), above n85, at 464-465.

94 On this issue, see the works listed in OUP UoF list (2020), above n6.

95 Following on from his affirmation in 1970, in the context of the Israeli occupation, that self-defense can justify the occupation of territory, quoted above in $n 85$, Steven Schwebel stated that "[a]s a condition of its withdrawal from [occupied] territory, [the occupying] state may require the institution of security measures reasonably designed to ensure that that territory shall not again be used to mount a threat or use of force against it of such a nature as to justify exercise of self-defense." Schwebel (1970), above n79, at 345-346. 
The final question implies that, indeed, the right or otherwise to maintain an occupation might be determined by whether or not a peace agreement is reached. ${ }^{97}$ Benvenisti takes this view by observing that "[n]either the Hague Regulations nor the [the Fourth Geneva Convention of 1949] limits the duration of the occupation or requires the occupant to restore the territories to the sovereign before a peace treaty is signed" (id.).

Given that occupation law (the treaties being referred to) regulates occupations when they happen, rather than addressing their existential legitimacy, this is to be expected. The issue is what the law on the use of force would have to say on the matter. Benvenisti quotes the 1948 Hersch Lauterpacht version of Oppenheim's International Law, that

If a belligerent succeeds in occupying the whole, or even a part, of enemy territory, he has realized a very important aim of warfare. He can now not only use the resources of the enemy country for military purposes, but can also keep it for the time being as a pledge of his military success, and thereby impress upon the enemy the necessity of submitting to terms of peace ...98

Eyal Benvenisti mentions UNSC Resolution 242 (1967), suggesting that, given that the resolution mentions withdrawal as an element of establishing a "just and lasting peace" in the Middle East, it is therefore in line with this "position."99 But the resolution doesn't stipulate that the occupation can be maintained until a "just and lasting peace" has been reached in the Middle East, nor does it purport to give Israel the authority to maintain it.100

97 Elsewhere, Benvenisti states that "because occupation does not amount to sovereignty, the occupation is also limited in time and the occupant has only temporary managerial powers, for the period until a peaceful solution is reached." Benvenisti (2012), above n22, at 6 (emphasis added).

98 Hersch Lauterpacht, Oppenheim's International Law 432 (7th ed. 1948) (emphasis as added by Benvenisti, in id., at 245). Benvenisti's treatment of an earlier version of the same quotation is discussed below, text accompanying nı62.

99 Id. S.C. Res. 242 (1970), above $\mathrm{n} 75$.

100 In the resolution, the UNSC affirms that: "the fulfilment of Charter principles requires the establishment of a just and lasting peace in the Middle East which should include the application of both the following principles: (i) Withdrawal of Israel armed forces from territories occupied in the recent conflict (ii) Termination of all claims or states of belligerency and respect for and acknowledgment of the sovereignty, territorial integrity, and political independence of every State in the area and their right to live in peace within secure and recognized boundaries free from threats or acts of force." S.C. Res. 242 (1970), above n75, para. 1. Here, the UNSC is merely stating that a "just and lasting peace" would require both an end to the occupation and the resolution of all the matters in 
Appraising the "position" more generally: it would only be lawful if the conditions for lawful self-defense necessitating the occupation are and continue to be met. ${ }^{101}$ Understanding the duration of an occupation as contingent on the adoption of a peace agreement is only legally possible if, separately, and in any case, the occupation remains justified according to the ad bellum test. A right to use force, including to conduct an occupation, is determined by the nature of the threat only, not also the presence or absence of a peace agreement. To be sure, an agreement can remove the threat. The ending of the threat and the adoption of the agreement can amount to the same thing. But if the threat is no longer present, either at all, or in in a manner that justifies, as necessary and proportionate, a use of force involving an occupation, there is no longer a lawful basis for the occupation, even if no peace agreement has been reached. At that point, the occupant has no "right to retain control" and

the second sub-paragraph. It does not follow from this that the occupation can therefore continue until there is the "just and lasting peace" that also covers the resolution of all the matters in the second sub-paragraph. Or, put differently, that in the absence of any of the elements a "just and lasting peace" it requires as set out in the second subparagraph, an absence of the element it sets out in the first sub-paragraph - the end to the occupation - is thereby justified. That would be a non sequitur. The occupation still has to be justified in self-defense terms, or on the basis of the UNSC lawfully providing authority to Israel to conduct it. The provision of authority to use force only emerged in the practice of the UNSC much later than when Resolution 242 was adopted. And key elements for it - the UNSC acting under Chapter VII, determining the situation to constitute a threat to international peace and security, and calling upon the state to use "all necessary means" - are all absent from this resolution (quite apart from what has already been said about the intended meaning of the relevant provisions). Equally, the practice of the UNSC in purporting to alter the position when it comes to states' rights and obligations in international law, that might in a different fashion from providing authority to use force, somehow render lawful an occupation that would otherwise be illegal, only emerged in the UNSC much later than when 242 was adopted. And again, key necessary elements are missing: the council merely "affirms" a position (less than clearly determinative language); it is not acting under Chapter VII; it does not directly address member states and their behavior and legal position. On the UNSC authorization basis for using force in international law, see the relevant sections of the works listed in OUP UoF list (2020), above n6. For a discussion of Resolution 242 and other UN determinations, see, e.g., Imseis (2018/2022), above n16, Imseis (2020), above n16. Note also in particular S.C. Res. 476 (1980), above n75, para. 1, where the Security Council "Reaffirms the overriding necessity to end the prolonged occupation of Arab territories occupied by Israel since 1967, including Jerusalem" (emphasis in original).

101 So, for example, Steven Schwebel, discussing the situation in 1969, states that "Israel's action in 1967 was defensive ... since the danger in response to which defensive action was taken remains, occupation-though not annexation-is justified, pending a peace settlement" (emphasis added). Schwebel (1970), above n79, at 344. However, see Schwebel's elaboration of what the "danger" test can justify, above n95. 
has a "duty to relinquish control." Moreover, defining the threat for use of force purposes in terms of a potential future threat - the aforementioned doctrine of pre-emptive self-defense - is not a credible position in the law on the use of force. ${ }^{102}$ There is no right to maintain the occupation simply as a defensive measure against the territory becoming a source of future attacks. ${ }^{103}$

In any case, Benvenisti states certain UNGA resolutions relating to the $\mathrm{oPt}$ "can be seen as an effort to revise" the "position" as he sees it having been set out in UNSC Resolution 242. ${ }^{104}$ These resolutions "voiced another message ... that occupation in itself is unlawful or at the very least, that the occupant is not entitled to delay a peaceful solution of the conflict."105 In the light of this, Benvenisti sets out his view thus:

It is suggested that an occupation regime that refuses earnestly to contribute to efforts to reach a peaceful solution should be considered illegal. Indeed, the failure to do so should be considered outright annexation. The occupant has a duty under international law to conduct negotiations in good faith for a peaceful solution. It would seem that an occupant which proposes unreasonable conditions, or otherwise obstructs negotiations for peace for the purpose of retaining control over the occupied territory, could be considered a violator of international law.106

But quite separately from any considerations arising out of the failure to pursue a settlement in good faith, to be lawful an occupation would still have to meet the ad bellum standards, on an ongoing basis. If it does not, which is the case here, then, as mentioned, the occupation is in any case illegal in use of force terms and needs to end immediately for this reason. There is no other "position" to account for that would change this, as a matter of what is operative in international law, whether as articulated by UNSC Resolution 242, Lauterpacht, or Benvenisti. ${ }^{107}$

102 The doctrine of a pre-emptive right to use force in self-defense came to prominence in the context of the US response to the attacks on September 11, 2001. It is not supported by the majority of states or most independent international law experts. See the general sources in the OUP UoF list (2020), above n6, many of which cover this topic.

103 Thus, the position set out by Schwebel (1970), above n95, is incorrect as a statement of the law on the use of force.

104 Benvenisti (2012), above n22, at 245 .

$105 I d$., at 245. On these resolutions, see Imseis (2018/2022), above n16, Imseis (2020), above n16 (and sources cited therein).

106 Benvenisti (2012), above n22, at 245 .

107 Benvenisti returns to the "position" later in his work; this is addressed below, text accompanying nı62. UN determinations, including S.C. Res. 242 (1967), have been understood 
In a separate section of his work, not specifically addressing the oPt, Benvenisti makes a similar point to that set out in the preceding quotation, about the significance of refusing to negotiate. Here, he expressly invokes legality in use of force terms, via the concept of aggression as defined in the Rome Statute for the International Criminal Court:

While an occupation that results from a defensive attack will obviously not be regarded as a "crime of aggression" because it would not constitute "a manifest violation of the Charter of the United Nations," ... a question will arise whether the occupant, which had seized control in a lawful war of self-defense but refuses to negotiate withdrawal would have criminal responsibility. Arguably, this occupant cannot be considered an "invader" or "attacker;" but to the extent that its presence amounts to a de facto annexation, it might pass the two thresholds of an "act of aggression" and a "crime of aggression."108

(In addressing an "occupation that results from a defensive attack" Benvenisti is perhaps using the term "defensive attack" to refer to a use of force in self-defense by the state that goes on to perform the occupation as part of the same overall defensive move [the terminology of "attack" is more commonly used only in the context of an unlawful use of force, as in the reference to "armed attack" in UN Charter article 51]). Again, Benvenisti's question is not the only one that is dispositive of the matter of compliance with the applicable law. Regardless of a refusal to negotiate (and whether or not the presence amounts to de facto annexation), if the circumstances that rendered an initial seizure of control lawful in self-defense terms change (the necessary threat and/or proportionality tests are no longer met) then the law has been breached (and, of course, if the initial seizure was unlawful then the occupation has been illegal from the outset). ${ }^{109}$

It is also necessary to account for how certain practices conducted during the occupation have breached IHL in general and occupation law in

to justify prolonging the occupation until there is an agreement. This is discussed below, text accompanying n155 et seq.

108 Benvenisti (2012), above n22, at 340 (fns omitted).

109 The distinction between an "act of aggression" (the general term denoting state responsibility) and the "crime of aggression" (giving rise to individual criminal responsibility) in the Rome Statute is beyond the scope of this article. For the definitions, see Rome Statute art. 8 bis, paras. 1 \& 2, above n54. Note that Benvenisti discusses his concept relating to the ending of an occupation a third time in his work. This is addressed below, text accompanying n162 et seq. 
particular. ${ }^{110}$ These include the treatment of the Jahalin and their homes, and the plan to forcibly relocate them to near the refuse dump in Abu Dis. Are these jus in bello violations significant for ad bellum legality? Such violations have been wide-ranging, some falling into the categories of "grave breaches" of the Geneva Conventions, and "other serious violations" of IHL, thereby constituting war crimes. ${ }^{111}$ One example, falling into the latter category, is implanting settlements into the oPt, including the settlements next to Khan al-Ahmar. ${ }^{112}$ Moreover, more generally, certain practices have constituted unlawful racial discrimination in general and apartheid in particular. ${ }^{113}$ These have constituted, in the case of apartheid, an international crime, and, when they have been part of an attack, crimes against humanity. ${ }^{114}$ Relatedly, the foregoing norms are classified as peremptory, jus cogens norms, which are non-derogable - they cannot be limited by any other areas of international law. ${ }^{115}$

The placing of these violations in an exceptional category, as giving rise, in certain cases, to their classification as international crimes, and having jus cogens status, reflects an idea that they can never be justified, including by other rules of international law. For present purposes, this means the law on the

110 See, e.g., the treatment of some of these issues in the ICJ Wall Advisory Opinion, above $\mathrm{n} 75$, at 114-147. On the Jahalin, see the sources cited above n2. For a treatment of initial phase of the occupation, see, e.g., Yahia (1970), above n16, at 163-177.

111 On these types of violations and their classification as war crimes, see Rome Statute art. 8, above $n 54$.

112 On the illegality of implanting settlements under occupation law, see the sources cited above n31. On the illegality of the Israeli settlements, see, e.g., ICJ Wall Advisory Opinion, above $\mathrm{n}_{75}$, at $115^{-120}$.

113 See John Dugard \& John Reynolds, Apartheid, International Law, and the Occupied Palestinian Territory, 24 Eur. J. Int'l L. 867 (2013); Michael Sfard, Legal Opinion: The Israeli Occupation of the West Bank and the Crime of Apartheid, Yesh Din (2020); Susan Power, The Legal Architecture of Apartheid, Against Apartheid and Racial Discrimination, AARDI/Al-Haq (Apr. 2, 2021), https://aardi.org/2021/04/o2/the-legal-architecture -of-apartheid-by-dr-susan-powers-al-haq/; Human Rights Watch, A Threshold Crossed: Israeli Authorities and the Crimes of Apartheid and Persecution (Apr. 27, 2021), https:// www.hrw.org/report/2021/04/27/threshold-crossed/israeli-authorities-and-crimes-apart heid-and-persecution.

114 See Rome Statute art. 7, above n54.

115 On peremptory norms, see Vienna Convention on the Law of Treaties art. 53, May 23, 1969, 1155 U.N.T.S. 331; I.L.C., Articles on Responsibility of States for Internationally Wrongful Acts, with commentaries, art. 41(2) U.N. Doc. A/56/10 (2001); I.L.C., Peremptory norms of general international law (jus cogens)), Text of the draft conclusions and draft annex provisionally adopted by the Drafting Committee on first reading, U.N. Doc. A/CN.4/L.936 (2019) (according to the ILC study, the following constitute jus cogens prohibitions (selected list): (c) The prohibition of crimes against humanity; (d) The basic rules of international humanitarian law; (e) The prohibition of racial discrimination and apartheid.). 
use of force. Thus, any use of force justification for the occupation associated with them is taken beyond the thresholds of necessity and proportionality. ${ }^{116}$ They are regarded to be inherently unnecessary and disproportionate. They cannot be justified through a link back to the just cause of self-defense (assuming it is in operation). Either they cross certain red lines of humane treatment (e.g. racial discrimination), or they are of their nature unconnected to that just cause and may, indeed, be linked to another cause that can never serve as a basis for lawful military action (e.g. implanting settlements, linked to annexation). ${ }^{117}$

Consequently, the violation of these norms is not only a matter of their "own" internal normative standards, as it were, including the jus in bello/IHL/ occupation law. It also has implications for the issue of the legality of the use of force. ${ }^{118}$ The in bello legal standards are not concerned with the existential legitimacy of the occupation. But the ad bellum legal standards which are concerned with this matter include within them a test, of necessity and proportionality, which is breached if the former standards are breached. In consequence, a violation of the former standards affects the existential legitimacy of the occupation as a matter of the latter standards. Thus, a state breaching peremptory norms of IHRL and IHL, including occupation law, during an occupation acts beyond what is justified by the law on the use of force. This renders the occupation in and of itself illegitimate as a matter of the latter rules.

That said, such illegitimacy could be remedied by bringing the practice into line with the rules. Viz., a complete reversal of key components of the occupation, including, for example, removing settlements. If this happened, the ad bellum requirements of proportionality and necessity would not be breached, insofar as the indirect link to the IHL rules are concerned.

Left to be determined would be whether the requirements of proportionality and necessity are met insofar as the link to the requirements of self-defense are concerned. As mentioned, such a determination leads to a conclusion of illegality. It is only this consideration, then, concerning the occupation's purpose, not its conduct, that is ultimately dispositive of its existential legitimacy in international law. If this test were not met, it would not matter whether breaches of the in bello standards also rendered the occupation unlawful in ad bellum terms because of their significance for the necessity/proportionality test. The occupation is "already" unlawful and thereby existentially

116 See, generally, the treatment of the interface between the jus ad bellum and the jus in bello in the sources contained in OUP UoF list (2020), above n6.

117 Id.

118 Id. 
illegitimate - these considerations just aggravate the illegality. If the test were met (which is not the case) then the occupation would, as a matter of the law on the use of force, have elements of legality (it has a just cause and is a proportionate means of meeting that cause) and illegality (aspects of its conduct are unjustified).

In addressing the significance of the law on the use of force for the legitimacy of the occupation, it is necessary finally to appreciate a fundamental feature of the legal framework being applied. This concerns the frame of reference adopted by the main component of the legal test: Israel's security needs. The law of self-defense concerns what these security needs are, what Israel should be allowed to do to meet them, etc. The question of the legitimacy of the occupation is assessed according to such considerations. Necessarily, assessing this question as a matter of the position of the Palestinian people is not a direct consideration. The latter position has to accommodate whatever is justified according to the legitimate security needs of Israel insofar as such justification is accommodated by the self-defense test. Put differently, the focus is on the link between the occupation and its effect on the security objective. It is not on the link between the occupation and its effect on the people in the territory affected. In consequence, whether or not the occupation is deemed legitimate has nothing to do directly with the latter effect. Thus, to speak of the "illegal occupation" as a matter of the law on the use of force is to invoke standards that frame the situation as not as oppression and denial of freedom, but as an excess of legitimate administrative authority. The position is different if the term is being used to denote illegality as a matter of the jus in bello. Here, the illegality is conceived in part in relation to standards concerning "humane" behavior.

The end result of applying the ad bellum standards - that the occupation is existentially illegitimate - might be the same were different standards, concerned directly with the impact on the Palestinian people, in play. But the law's significance is not simply about the position arrived at when it is applied to any given situation, important though that is. It is also about the journey to that position. How is the situation the position relates to portrayed? What factors are regarded as significant or not? To whom are these factors significant? Palestinian people seeking to vindicate their struggle using the terminology of the law on the use of force must do this without referring to the direct impact of the occupation on themselves. Rather, the only direct focus permitted is Israel's defensive security needs. Equally, and in reverse, Israeli people seeking to justify the occupation through this legal framework are able to focus directly only on their own defensive security needs. They are not having to account directly for the effect of the occupation on the Palestinian people. When it 
comes to what is discussed, analyzed, and weighed in the balance, Israel's defensive security needs are in the foreground; the rights of the Palestinian people are in the background. Not only, then, does the occupation exist as a matter of fact, as a practical instantiation of the domination of one people over another. Also, the way this area of international law treats such a situation is to assess things with reference to the needs of the dominant actor directly, and the needs of the subaltern actor indirectly.

So, the international law ad bellum and in bello frameworks operate as a double bind, offering competing approaches operating dialectically when it comes to their key merits and shortcomings. Palestinian people can invoke their own needs directly but in doing must be silent, when it comes to what these needs cover, on their fundamental aspirations to freedom (in bello). Alternatively, they can invoke those aspirations to freedom but must do so through the prism not of their own needs, but, rather, the interests of Israel (ad bellum).

\section{Self-Determination as a Legal Right}

The other main area of international law addressing the existential legitimacy of the occupation is the law of self-determination. ${ }^{119}$ The focus moves away from Israel's security needs (as in the law on the use of force), towards the position of the Palestinian people. Their right of self-determination in international law is universally recognized including, crucially, the right in its "external" manifestation, including an entitlement to choose their international status (e.g. statehood). ${ }^{120}$

119 The authorities on this topic are voluminous. See Thomas Burri \& Daniel Thürer, Self-Determination, Max Planck Encyc. Pub. Int'l L. (Dec. 20o8), https://opil.ouplaw.com/ view/10.1093/law:epil/978019923169o/law-978019923169o-e873?prd=EPIL; Oxford University Press, Oxford Bibliographies - Self-Determination in International Law, https:// www.oxfordbibliographies.com/view/document/obo-978o199796953/obo-978o199 796953-0033.xml; and the sources list in Wilde (2008), above n18, Section 5.4, at 541. See also, in particular, International Covenant on Civil and Political Rights art. 1, Dec. 16, 1966, 999 U.N.T.S. 171 [hereinafter ICCPR]; International Covenant on Economic, Social, and Cultural Rights art. 1, Dec. 16, 1966, 993 U.N.T.S. 3 [hereinafter ICESCR]. On self-determination as a "human right," see further below, text accompanying n187 et seq.

120 In the words of the ICJ, "[a]s regards the principle of the right of peoples to self-determination, the Court observes that the existence of a 'Palestinian people' is no longer in issue." ICJ Wall Advisory Opinion, above n75, para. 118. See, e.g., Sally Morphet, The Palestinians and their Right to Self-Determination, in Foreign Policy and Human Rights: Issues and Responses (R.J. Vincent ed., 2009); Cassesse (1995), above n8o, at 23047 (and sources cited therein); and G.A. Res. 44/48(A-G) (Dec. 8, 1989). 
External self-determination was the means through which the international political system, including international law, purported to accommodate the struggle for colonial liberation in the second half of the twentieth century. "Freedom" meant the right of colonial peoples to constitute themselves as states, thereby enjoying formal sovereign "equality" with the states that had been their colonial masters. To attain this, then, colonial peoples were required to accept the state as the primary basis for their collective identity to adopt the form of association that colonizing societies had adopted for themselves in the metropolis. ${ }^{121}$ This echoes Frantz Fanon's observation in the context of colonialism that "it is on that other being, on recognition by that other being, that his own human worth and reality depend."122 Thus statehood was, in the words of Makau Mutua, "imposed." 23 Forms of collective identity other than statehood or variants that presupposed its validity as the primary model of association (e.g. assimilation into another state) were not implemented. ${ }^{124}$ Moreover, the particular territorial unit and associated population for each state followed the boundaries adopted by colonial authorities to divide their spheres of influence - the legal concept of uti possidetis juris regardless of any meaningful connection with how societies were collectively constituted. ${ }^{125}$ This can be critiqued as, in the words of Makau Mutua writing

121 On this process, see Mutua (1994), above n12; Anghie (2005), above n12, passim.

122 Frantz Fanon, Black Skin, White Masks 216-217 (1967).

123 Mutua 1994, above n12.

124 UNGA Resolution 1541 sets out three scenarios whereby a "Non-Self-Governing Territory can be said to have reached a full measure of self-government": (a) Emergence as a sovereign independent State; (b) Free association with an independent State; or (c) Integration with an independent State. G.A. Res. 1541 (XV) (Dec. 15, 1960), Annex, Principle VI. The later G.A. Res. 2625, the Declaration on Friendly Relations and Co-operation, stipulates the options for external self-determination in the following terms: "[t]he establishment of a sovereign and independent State; the free association or integration with an independent State or the emergence into any other political status freely decided by a people ..." G.A. Res. 2625 (XXV). The terms of the third option might suggest that some non-sovereign-state-based outcome is possible. On these two formulations, see ICJ Western Sahara Advisory Opinion, above n75, paras. $57 \& 58$. The fact that the implementation of the right has in fact always stayed within sovereign-state-based options is perhaps why, in his description of these options, James Crawford follows the approach taken in Resolution 1541 only, without reference also to Resolution 2625. James Crawford, The Creation of States in International Law 621 (2nd ed., 2007) [hereinafter Crawford (2007)]. He summarizes the position thus: "[s] elf-determination can result either in the independence of the self-determining unit as a separate State, or in its incorporation into or association with another State on a basis of political equality for the people of the unit." Id., at 128 .

125 Mutua (1994), above n12. On the doctrine of uti possidetis juris, see, e.g., Frontier Dispute (Burkina Faso/Republic of Mali), Judgment, 1968 I.C.J. Rep. 554 (Dec. 22), paras. 19-26. 
about decolonization in the continent of Africa, a "false" concept of collective identity that constituted a "straight-jacket which continues to deny freedom to millions of Africans." 126 Moreover, "freedom" operated exclusively through a narrow, formal notion of sovereign equality allied to self-rule understood only in terms of the absence of direct colonial administration. This ignored more broad-ranging, complex relations of domination and dependency, notably in the economic sphere, which could continue in the supposedly "post-colonial" period of "liberation." 127

This is the particular form of "freedom" that the international law of self-determination offers the Palestinian people. Collective identity must be channeled through a link to the territory of the colonial Mandatory Palestine (the League of Nations Mandates were internationally supervised colonies), and via a claim to sovereign statehood. Moreover, within this, the territorial parameters of realizing self-determination through statehood are generally understood to be not those of Mandatory Palestine in its entirety. Israel was formed in part of that entity, being recognized by states and the UN as a sovereign state. In consequence, as a matter of international law, the Palestinian people are supposed to settle for that which is "left": the West Bank and Gaza. ${ }^{128}$

In that decision, concerning the boundary between two African states, the Court stated that: "At first sight this principle [of uti possidetis juris] conflicts outright with another one, the right of peoples to self-determination. In fact, however, the maintenance of the territorial status quo in Africa is often seen as the wisest course, to preserve what has been achieved by peoples who have struggled for their independence, and to avoid a disruption which would deprive the continent of the gains achieved by much sacrifice. The essential requirement of stability in order to survive, to develop and gradually to consolidate their independence in all fields, has induced African States judiciously to consent to the respecting of colonial frontiers, and to take account of it in the interpretation of the principle of self-determination of peoples." Id., para. 25 .

126 Mutua (1994), above n12, at 1175 .

127 See, e.g., Anghie (2005), above nı2; Chimni (2006), above nı2; John Linarelli et al., The Misery of International Law: Confrontations with Injustice in the Global Economy (2018) (and sources cited therein).

128 This position follows from the status of Israel as a state in international law, and its membership as such of the UN. It is advanced by the commentators and authorities cited herein. It should be acknowledged, however, that there nonetheless remains a challenge to this position: that the entirety of the territory and associated population of Mandatory Palestine constitute a single self-determination unit and remain as such, the creation of Israel as a state notwithstanding. In the first place, such a position is based on the treatment of the population of Mandatory Palestine under Article 22 of the League of Nations Covenant, who were, under that instrument, deemed to "have reached a stage of development where their existence as independent nations can be provisionally recognized." Covenant of the League of Nations, Versailles, June 28, 1919. In the second place, either as a supplement or an alternative to this, it is based on an argument that self-determination 
So James Crawford observes that " $\mathrm{t}] \mathrm{he}$ people of Palestine (i.e. of the remaining territories of the Mandate for Palestine) have a right of self-determination." ${ }^{129}$ The International Court of Justice (ICJ) ended its Advisory Opinion on the legal consequences of the Wall constructed by Israel in Palestinian territory, in which it affirmed the Palestinian right to self-determination, by drawing the UNGA's attention to the need to achieve "the establishment of a Palestinian State, existing side by side with Israel."130 Antonio Cassese even suggests that the sole ground for the Palestinian people having a right to self-determination in the first place is the occupation (rather than the occupation being simply a denial of this right). ${ }^{131}$ Moreover, because of this, "it follows that only those Palestinians living in the territory occupied by Israel since 1967 are entitled to the exercise of this right."132

For people whose primary understanding of collective identity does not fit with sovereign statehood (whether current or future), such as the Jahalin, a Bedouin nomadic people, the foregoing arrangements for self-determination, concerned with issues of sovereignty and statehood, are at odds with this identity. Moreover, these arrangements reinforce the very matters which led to their displacement after the creation of Israel and continue to prevent their return. In a form of international law gaslighting, self-determination is only relevant to the legal status of the territory they were displaced to (West Bank Palestine), while maintaining the legal status of the place they were displaced from (the state of Israel), the establishment of which their displacement, as part of the Nakba, played an integral part in enabling.

Moreover, Cassese bases the existence of the Palestinian people's right to freedom exclusively in being denied the exercise of this right by the occupation. As will be explored further, he posits self-determination as an approach to a legal entitlement rooted in the perspective of the people. ${ }^{133} \mathrm{But}$ the definition of who constitutes that people is not determined by that perspective. Instead, the starting point is the Israeli perspective. What is

had become applicable to colonial territories, including Mandatory Palestine, before the UN partition resolution of 1947. In consequence, the entire population and territory of Mandatory Palestine constituted a self-determination unit at that time, and the partition resolution, and Israel's secession from Mandatory Palestine in 1948, did not alter this. A treatment of this challenge to the orthodox position is beyond the scope of the present article.

129 Crawford (2007), above n124, at 444.

130 ICJ Wall Advisory Opinion 2004, above $\mathrm{n} 75$, at 162 . This statement is discussed further below, text accompanying n2o6.

131 Cassese (1995), above n8o, at 240.

$132 I d$.

133 See text accompanying nı44 below. 
"occupied" is the Palestinian people for the purposes of self-determination. And what is "occupied" is legally defined as what is "not-Israel." Moreover, within this concept of collective self-determination arising out of a denial of freedom, only such a denial through the occupation is relevant. The position of Palestinian refugees as refugees, whether within the oPt, Israel or internationally, and their inability to return, is excluded. As is the lack of freedom for Palestinian people within Israel.

Overall, the master's tools of the international law of self-determination offer the Palestinian people in general, and the Jahalin in particular, to quote Samera Esmeir again, "itineraries for political life" which drastically diminish "the pursuit of collective freedom adequate to a non-colonial future."134

Within this drastically diminished itinerary, the law self-determination purports to provide the following protections. It is because the Palestinian people have the right of self-determination in this way that the oPt are not and have never been for the duration of the occupation terra nullius - territory that does not fall under the sovereignty of any international legal person. Rather, sovereignty resides in the Palestinian people. The territory has been and is either a non-state territorial self-determination unit, or the state of Palestine, depending on the view taken on whether or not the assertion of the latter status has been legally effective and, if so, when that happened. ${ }^{135}$

134 Esmeir, above n44.

135 The issue of whether Palestine is a state in international law (and when this might have happened) is beyond the scope of this article, and was the subject of much attention and commentary in 2020-21 in the context of the deliberations at the ICC on the question of Palestine's accession to the Rome Statute (above n54), bearing in mind the UNGA decision to upgrade Palestine's status at the UN from non-member entity to non-member state in 2012 (U.N. Doc. A/RES/67/19 (Dec. 4, 2012)). For some commentary on this topic, see, e.g., the relevant parts of the sources cited above n16. A territory that does not fall within the sovereignty of any state and is inhabited by people who have the right of external self-determination is not terra nullius. Rather, it has an international legal status where certain rights over the territory are vested in that people. The UNGA stated, in the context of self-determination, that "the territory of a colony or other Non-Self-Governing Territory ... has ... a status separate and distinct from the territory of the State administering it; and such separate and distinct status ... shall exist until the people of the ... territory have exercised their right of self-determination." G.A. Res. 2625 (XXV), above n124. See also the ICJ Western Sahara Advisory Opinion, above n19, paras. 80-81; and Crawford (2007), above n124, at 617-619. Writing in 2007, James Crawford took the position that Palestine was not a state, and in this context wrote "[t]he people of Palestine ... have a right of self-determination ... there is thus a non-State legal entity recognized as represented by a national liberation movement. This explains the 'capacity' of the PLO to perform various acts, to enter into treaties, to bear rights and assume obligations ... these are not things which in modern international law only States can do." Id., at 444. 
It is because the oPt has this status that the prohibition on annexation through the use of force applies. That prohibition is the modern articulation of a root to title based on "conquest" - taking territory by force from its "owner."136 For it to apply, there has to be a "sovereign" whose rights would be alienated through force. ${ }^{137}$ Given the likely status of the Mandatory Palestine in 1948 and 1967 - as non-state territory - it is only the right to self-determination that introduces an alternative, non-state-based "sovereignty" - vested in the Palestinian people - to trigger the force-enabled-acquisition-prohibition. Without self-determination (or the fanciful notion that the West Bank was somehow part of the territory of Jordan in 1967) the prohibition would not apply.

Another consequence of the oPt not being terra nullius is that Israel cannot acquire title on the basis of what is referred to in the law on title to territory as "occupation." This denotes the exercise, for a sustained period, of effective control over terra nullius ${ }^{138}$ (here, the concept is concerned with the acquisition of title through the conduct of occupation - in the law of occupation it used to define such conduct, which if in existence triggers a regulatory regime). This is related to but distinct from the earlier prohibition on annexation through the use of force. There, the focus of the international legal prohibition is on the forcible means through which sovereignty is alienated, for example by driving out and/or subjugating the existing sovereignty-holder. Here, the focus is on controlling the territory itself. Whereas the forceenabled-annexation prohibition is rooted in the notion of preventing, effectively, violence-enabled-theft, the occupation-enabled-annexation prohibition is rooted in the notion that there is already an "owner" and so acquisition of territory through control is inapplicable.

It is, thus, only because the Palestinian people have a right to selfdetermination that annexation cannot be effected through either the use of

${ }_{13} 6$ See the sources cited above $\mathrm{n}_{75}$; and, in particular, e.g., OUP Territorial Title list (2016), above n6; Jennings (1963/2017), above n75, Ch. IV.

137 Hence, Benvenisti defines the prohibition as being based on "the principle of inalienability of sovereignty through unilateral action of a foreign power, whether through the actual or threatened use of force ... Effective control by foreign military force can never bring about by itself a valid transfer of sovereignty" (emphasis added). Benvenisti (2012), above n22, at 42 .

138 On "occupation" as a root of title, see the sources cited in the OUP Territorial Title list (2016), above n6; in particular Jennings (1963/2017), above n75, at 33-37. For Robbie Jennings, writing in 1963 , "occupation is obsolescent except in relation to the Polar regions." Id., at 33. For Masaharu Yanagihara, occupation is "not usually relevant given the lack of terrae nullius." OUP Territorial Title list (2016), above n6. 
force (the "conquest" basis for title) or the exercise of effective control (the "occupation" basis for title).

Furthermore, given that the Palestinian people have not agreed that all or part of the oPt is to be Israeli territory, the default requirement of the law of self-determination is that they should be immediately freed from the impediments to self-rule. This includes freedom from impediments to self-rule realized through independent statehood. If the practical exercise of external self-determination is not happening because a state is exercising control over the territory, whether on the basis of colonial arrangements, or a military occupation, then, according to this logic, that state is obliged to bring the control to a speedy end. The matter of agreement by that state to the ending of its domination is legally irrelevant. The state is already subject to an obligation here. Such consent is legally otiose.

Moreover, crucially, the obligation to bring control to an end does not incorporate a consideration as to whether the people affected are "ready" for self-administration. In the classic formulation of UNGA Resolution 1514 (1960), "inadequacy of political, economic, social or educational preparedness should never serve as a pretext for delaying independence."139 The requirement that self-determination should be implemented immediately is a general doctrine, not specifically conceived in opposition to "preparedness" as a pretext for delay. In Resolution 1514, the UNGA "Solemnly proclaims the necessity of bringing to a speedy and unconditional end colonialism in all its forms and manifestations."140 And further states that:

Immediate steps shall be taken, in Trust and Non-Self-Governing Territories or all other territories which have not yet attained independence, to transfer all powers to the peoples of those territories, without any conditions or reservations, in accordance with their freely expressed will and desire ...141

Quoting these provisions, the ICJ in its Advisory Opinion about the Western Sahara described the application of self-determination as being "for the purposes of bringing all colonial situations to a speedy end."142

\footnotetext{
139 G.A. Res. 1514 (XV) (Dec. 14, 196o), para. 3 .

140 Id., pmbl.

141 Id., para. 5 .

142 ICJ Western Sahara Advisory Opinion, above nı, para. 55. See also what the ICJ called upon the UK to do in relation to the Chagos Islands in the ICJ Chagos advisory opinion, quoted below, text accompanying n2o8.
} 
To conclude, the occupation of the Palestinian territories by Israel is a violation of the right of Palestinian self-determination and Israel's concomitant obligation to take the necessary steps to enable this right to be realized. It is, moreover, an egregious violation, given its duration and bearing in mind the foregoing stipulations concerning speedy realization.

That said, such a conclusion can only be drawn after one has already adopted the earlier position that Israel's occupation does not meet the test for lawful self-defense as a matter of the jus ad bellum. Any occupation of inhabited land meeting the latter test necessarily negatively affects the enjoyment of the self-determination right of the population affected. Yet, it is not regarded as illegal for this reason. Thus, it is necessary, in order to invoke international law to challenge the legitimacy of the occupation, to make a case on the basis of both the law on the use of force and the law of self-determination. Moreover, the little expert legal analysis that has been done on the intersection between these regimes, by Antonio Cassese, takes the position under the law on the use of force, and reads this into the law of self-determination. Whatever is lawful as a matter of the former is thereby not unlawful as a matter of the latter. ${ }^{143}$ Having set this approach out, Cassese observes that

The right to external self-determination is thus, in a sense, the counterpart of the prohibition on the use of force in international relations. In many cases, the breach of external self-determination is simply an unlawful use of force looked at from the perspective of the victimized people rather than from that of the besieged sovereign State or territory. ${ }^{144}$

143 For Cassese: "military occupation ... amounts to a grave breach of Article 1(1) [of the ICCPR] (such action is not in conflict with Article 1(1) if it is justified by Article $5^{1}$ of the UN Charter and, therefore, being restricted to repel an act of aggression, is limited in duration)." Cassese (1995), above n8o, at 55. In a later passage in the same work, he elaborates on this theme: "self-determination is violated whenever there is a military invasion or belligerent occupation of a foreign territory, except where the occupation - although unlawful - is of a minimal duration or is solely intended as a means of repelling, under Article 51 of the UN Charter, an armed attack initiated by the vanquished Power and consequently is not protracted." Id., at 99. It is not clear what Cassese means in the second quotation, that the exception to a violation of self-determination he is setting out covers an occupation he still characterizes as "unlawful." In the first quotation, he states that an occupation constituting a lawful use of force "is not in conflict with" the provision on self-determination in the ICCPR. It is submitted that the legal position is as set out in that first quotation.

$144 I d$., at 99 (emphasis in original). 
It is correct that the law of self-determination shifts the focus of the effect of military action justified by the use of force to the population subjected to it (the Palestinian people) in preference to a focus on the collective entity with which they are associated (Palestine). But more fundamentally, the law on the use of force test is not anyway concerned directly with the "perspective" of the object of force, whether a state/non-state territory or a people. The test is an appraisal of the legitimacy of the defensive claims made by the state using force. Thus, setting the boundaries of legality under the law of self-determination according to legality under the law on the use of force flips things back to the "perspective" of the occupying state. The law of self-determination does not, therefore, provide an escape from needing to articulate a case assessing whether Israel's defensive needs legitimize the occupation. This is not a test concerned directly with the "perspective of the victimized people."

\section{Self-Determination Delayed and Potentially Dropped}

The common way of understanding the extended duration of the occupation stops at the present stage of analysis: it is a prolonged violation of international law, as has been the case for the people of the Western Sahara since 1975, and as was the case for the people of Timor Leste between 1975 and 1999. However, the link with these examples suggests something more than simply a common practice of lengthy illegality. As this section explores, there are certain trends in the way law is understood that partly explain how its violation has persisted for so long.

It is not unusual for states and the UN to treat situations like the Israeli occupation of the Palestinian territories, where the right of external selfdetermination applies, as if there is no requirement of immediate termination. The delay in realizing external self-determination is treated as permissible and, even, required. And it can sometimes pave the way for an approach to realizing the right incorporating determinative factors which are incompatible with how the exercise of the right is supposedly understood.

After a quarter of a century of Indonesian occupation the people of Timor Leste, who had a right of external self-determination as the inhabitants of a former Portuguese colony, were permitted to realize this right through independent statehood (after the outcome of a popular consultation). However, Indonesia and Portugal - the occupier and former colonial power - with the blessing of the UNSC, decided that statehood would not be realized immediately. Rather, there would first be a period of administration by the 
UN, on the basis that, in the immediate term, the people of Timor Leste were deemed incapable of self-administration. ${ }^{145}$ The UNSC created a UN administrative authority - the UN Transitional Administration in East Timor (UNTAET) - to do this. ${ }^{146}$

In Iraq, the US and UK and the UNSC generally conceived the end of the occupation as linked to the question of when the local population would be "ready" to take over control. On this basis, the USNC authorized the CPA to engage in the political, economic, and legal transformation deemed necessary to create the conditions for "readiness," a process that would take place before "sovereignty" would be "transferred" to the Iraqi people's representatives. ${ }^{147}$

In Western Sahara, the idea of linking implementing self-determination to the reaching of an agreement with Morocco has taken hold in UNSC determinations. This has joined the more long-standing, seemingly endlessly deferrable, matter of delaying such implementation until a referendum of the Sahrawi is conducted. A UN peace operation created in 1991 to conduct the referendum, the UN Mission for the Referendum in Western Sahara (MINURSO), has not done this, for 20 years and counting. ${ }^{148}$ When MINURSO was created, the UNSC stated its commitment to a "just and lasting solution to the question of Western Sahara." ${ }^{149}$ Almost twenty years later, in the most recent resolution on the matter, adopted in 2020, the way the UNSC conceives the "solution" reflects an important shift. It is not to be a "just and lasting" - only solution; it is to be

a just, lasting, and mutually acceptable political solution, based on compromise, which will provide for the self-determination of the people of Western Sahara in the context of arrangements consistent with the principles and purposes of the Charter of the United Nations. ${ }^{150}$

On the one hand, the solution is to be just, and provide for self-determination. Arrangements have to be consistent with the purposes and principles of the UN Charter, implicating the Charter objectives to "bring about ... in conformity with the principles of justice and international law [the] adjustment or

\footnotetext{
145 See the sources cited above n2o.

146 Id.

147 See the sources cited above n22.

148 See UN Missions, MINURSO (2021), https://minurso.unmissions.org/.

149 S.C. Res. 690 (Apr. 29, 1991), pmbl.

150 S.C. Res 2548 (Oct. 30, 2020), pmbl. This formulation is repeated in the operative paragraphs (with some important modifications in some places, see, e.g., the extract from para. 2 herein).
} 
settlement of international disputes" and "to develop friendly relations among nations based on respect for the principle of equal rights and self-determination of peoples." 151 On the other hand, the solution is to mutually-acceptable, i.e. acceptable to both the Sahrawi and the occupying state, Morocco. And it is to be based on compromise, presumably implying that both sides might have to give certain things up to enable mutual acceptance.

The Sahrawi might, of course, freely choose compromise. And this might enable Moroccan agreement. If validated through a free and fair referendum meeting the relevant standards, this could potentially constitute a valid exercise of self-determination. But what if they freely determine otherwise? Preferring an outcome lacking compromise, which Morocco disagrees with? These stipulations seem to rule out such an outcome. But if the people of the Western Sahara have a right to self-determination, then it is supposed to be their view alone that is determinative of the "solution." And if the solution is to be one that is "just," and "just" means lawful in international law - and so in "conformity with the principles of justice and international law" - then the consent of Morocco cannot be a necessary requirement. ${ }^{152}$

It is unsurprising, therefore, that the referendum has not happened, since holding it would shift the focus onto the Sahrawi position as being potentially exclusively determinative of the solution. Strikingly, in the 2020 UNSC resolution, which is lengthy, there is no reference the holding of the referendum. And the mandate of MINURSO, which has the word referendum in its name, is discussed without reference to this task. Indeed, the key operative paragraph relating to that mandate states the following:

Emphasizes the need to achieve a realistic, practicable and enduring political solution to the question of Western Sahara based on compromise and the importance of aligning the strategic focus of MINURSO and orienting resources of the United Nations to this end. ${ }^{153}$

This does not even attempt, as the preamble does, the uneasy balance between the two contradictory elements. The UN mission created to conduct

\footnotetext{
151 U.N. Charter art. 1, paras. 1 \& 2.

$15^{2}$ As James Crawford observes: "where the principle [of self-determination] applies, it does so as a right of the people concerned; it is not a matter simply of rights and obligations as between existing States. Another State may well be interested in the result of an act of self-determination, in that it may stand to gain or regain territory. But to treat self-determination as a right of that State would be to deny the reality of the alternative options open to the people concerned." Crawford (2007), above n124, at 618.

153 S.C. Res. 2548 (2O20), above n15o, para. 2.
} 
the self-determination referendum that would potentially place the decision exclusively in the hands of the Sahrawi is instructed to adopt a "strategic focus" on a solution rooted only in what is "realistic" and "based on compromise." And to do so without having to account for whether the solution is "just" and provides for self-determination. It is as if the name of the mission, with its reference to a referendum and the implicit link this makes to self-determination, is an unfortunate hangover from, and, as such, an embarrassing reminder of, an earlier position that has been abandoned.

Accordingly, the resolution of the question of Morocco's control of Western Sahara, including if it will end and, if so, when, is something that should depend on Morocco's agreement. Approaching Western Sahara on this basis is especially notable given that it concerns the very situation in relation to which the ICJ made its aforementioned general observation, based on UNGA Resolution 1514, that self-determination requires "bringing all colonial situations to a speedy end." It is one thing for such a situation not to end speedily because the occupying state refuses to comply with this requirement. And because other states fail to address effectively this non-compliance and, even, in the case of the US under President Trump, recognize Moroccan sovereignty over the territory. ${ }^{154}$ It is quite another for the UN, the supposed institutional guardian of the international legal order including the law of self-determination ( $c f$. those purposes and principles in the UN Charter) to treat the situation as not necessarily to be determined solely according to the wishes of population involved but, rather, also requiring the occupying state's agreement.

The foregoing approaches of linking the end of foreign rule to the meeting of particular conditions - whether normative standards being met (the people of Timor Leste and Iraq being "ready"), or the adoption of an "agreement" involving the foreign ruler's consent (Morocco and Western Sahara) - are at play in relation to the realization of Palestinian self-determination.

As Ardi Imseis argues, the discourse at the UN, and of the self-appointed "Quartet," links ending the occupation to the outcome of peace negotiations and/or the existence of governance in Palestine providing Israel with security guarantees. ${ }^{155}$ Thus, the security considerations from the use of force resurface. They are partially incorporated into a standard to be met before people are given freedom. Their significance now is not as a binding, ostensibly "objective"

154 On this recognition, see Donald J. Trump, Proclamation on Recognizing The Sovereignty Of The Kingdom Of Morocco Over The Western Sahara, Trump White House Archives (Dec. 10, 2020) [hereinafter Trump White House Archives (2020)], https://trumpwhite house.archives.gov/presidential-actions/proclamation-recognizing-sovereignty-king dom-morocco-western-sahara/.

155 Imseis (2018/2022), above n16; Imseis (2020), above nı6. 
test concerning necessity and proportionality to an existential threat. Rather, they constitute a broader standard. And their application is to be determined according to the outcome of negotiations - a political process. And this application only occurs when that outcome happens as a matter of fact. Moreover, as the outcome requires an agreement with Israel, the meeting of the test is not, as in the law on the use of force, determined irrespective of the decision taken on it by the actor to whom it applies. Rather, Israel's decision is an integral part of the test itself. Furthermore, the profoundly unequal negotiating position between Israel and Palestine creates the conditions for this decision to be the predominant determinant. Moreover, security considerations are unlikely to be the exclusive subject of the agreement. Broader matters, such as Israel's annexation aspirations over parts of the West Bank ("land for peace") can and are likely to be included.

The deferred, contingency approach to realizing Palestinian selfdetermination and/or ending the occupation is also evident in certain academic commentary. James Crawford reported in 2007 that " $[t]$ here is a substantial international consensus that the Palestinian people are entitled to form a State (subject to guarantees as to the security of the other States in the region)." ${ }^{\prime 56}$ Antonio Cassese stated in 1995 that: “... there is general agreement that the objective of granting Palestinians self-determination should go hand in hand with that of safeguarding the existence, security and independence of Israel as a sovereign State ... there is widespread agreement that these two objectives should be achieved through peaceful negotiations." ${ }^{157}$ Likewise is Eyal Benvenisti's position from earlier: the occupation can be maintained pending the conclusion of an agreement, if Israel is making good faith efforts to negotiate. ${ }^{158}$ Orna Ben-Naftali, Aeyal Gross, and Keren Michaeli offer a complementary proposal, that could presumably be activated if such efforts are absent:

The international community may wish to entertain the thought that, in cases of occupations lasting longer than a year, and pending a comprehensive political solution, the effective control over the occupied territory be transferred from the occupying power to an appropriate international authority. ${ }^{159}$

156 Crawford (2007), above n124, at 438 .

157 Cassese (1995), above n8o, at 240.

$15^{8}$ See above, text accompanying n1o6 et seq.

159 Ben-Naftali, et al. (2005), above n35, at 613 (fn omitted) (citing Orna Ben-Naftali, A La Recherche du Temps Perdu': Rethinking Article 6 of the Fourth Geneva Convention in the Light of the Legal Consequences of the Construction of a Wall in the Occupied Palestinian 
Nowhere do they suggest that for occupations of a people with a right to self-determination, like the Palestinian people - the very situation addressed in the article where they make the proposal - the law of self-determination requires a transfer of authority automatically and directly to this people. ${ }^{160}$ Similarly, Benvenisti's answer to his question, when discussing the oPt, "is there an obligation to end the occupation," does not mention self-determination at all, let alone address this aspect of it. ${ }^{161}$

Separately, in the final pages of the conclusion to the same work, Benvenisti returns to the subject of ending occupations, this time as a general matter. Now self-determination is expressly introduced as a consideration. He states that “[a] legal framework that respects human and peoples' rights can no longer support the thesis that the occupant may hold the territory 'as a pledge of his military success, and thereby impress upon the enemy the necessity of submitting to terms of peace."'162 Here, then, is a repeat quotation of the same Lauterpacht/Oppenheim "principle" (now termed a "thesis") Benvenisti discussed earlier in the oPt context. ${ }^{163}$ In his earlier oPt-specific treatment, Benvenisti discussed potential inroads made to the principle by UNGA resolutions concerning the occupation. This led him to adopt his position nuancing the principle, without referencing Palestinian self-determination as a consideration. ${ }^{164}$ Now, when discussing the termination question generically, self-determination is expressly referenced, and it is suggested that this renders the principle (now a thesis) unsupportable. It is unclear why Benvenisti did not expressly invoke self-determination when discussing the same issues in the context of the occupation of the Palestinian territories. ${ }^{165}$ That said, his articulation of his position on the question generically essentially follows the same lines as the position formulated earlier in the oPt context. As then, it amounts to a qualified version, not outright rejection, of the Lauterpacht/Oppenheim

Territory Advisory Opinion, 38 Isr. L. Rev. 211 (2005) (where Ben-Naftali makes the same point, at 228-9)).

16o The treatment of the right of the Palestinian people to self-determination in the article is limited to a footnote. Ben-Naftali et al. (2005), above n35, at 554-555 n18.

161 Reviewed above, text accompanying ng6 et seq. N.b. what is said below, n164, regarding the significance of the UNGA resolutions mentioned in that analysis.

162 Benvenisti (2012), above n22, at 348 (fn omitted) (citing the 1906 version of Oppenheim (2 Lassa Oppenheim, International Law: War and Neutrality 167 (1906)).

163 This time the citation for the quote is from an earlier edition of the same source. For the other citation of the later version of Oppenheim, see above n98.

164 Clearly, the position adopted by the UNGA in the resolutions on the illegality of the occupation was based in part on the self-determination right of the Palestinian people.

165 Although it is important to acknowledge the motivations that informed the resolutions he does mention, as indicated in the previous footnote. 
"principle"/"thesis": the occupation can continue if good faith efforts are made by the occupier to reach an agreement. ${ }^{166}$ Considering self-determination does not, then, seem to have made any difference. Certainly, the more fundamental challenge raised by this right to the continuance of the occupation - that it has to end immediately, unless justified in self-defense terms - is not discussed.

Cassese's "hand in hand" approach implicitly eliminates the element of the self-determination entitlement that would require its automatic realization, regardless of whether his other objective, concerning safeguards for Israel, is realized. This is remarkable coming from the same commentator who on a generic level articulated the self-determination-use of force interface in a manner that only permitted inroads into the former on the basis of what was justified according to the latter (considerably narrower than the objective of "safeguarding the existence, security and independence of Israel as a sovereign State").167

For both Benvenisti and Cassese, then, the coverage of self-determination differs when the occupation of the Palestinian people, rather than occupations generally, is discussed.

These academic approaches, and the more general trend Ardi Imseis identifies at the UN, corresponds to a broader pattern. The end of foreign rule is contingent on factors going beyond the view of the people with the right of external self-determination on the question. At play is a concept in international law and public policy, trusteeship over people, which has its origins in forms of post-Renaissance European colonialism. In previous work, I identified the links between these different forms of "foreign territorial administration," and the overall concept, which was itself often based on a racist distinction, the "standard of civilization," deployed to determine which people were deemed incapable of self-administration and which other "advanced" people were deemed fit to act as trustees. ${ }^{168}$ This term covers manifestations of colonialism (e.g. under the General Act of the 1899 Berlin Conference). It also covers other forms of colonialism supervised by international organizations - the League

166 Benvenisti (2012), above n22, at 348.

167 Cassese's general approach is reviewed above, text accompanying nu43 et seq. This is assuming that "hand in hand" means there cannot be one without the other, as a matter of legal position. An alternative interpretation of this could be, more loosely, that it would be desirable to have both objectives achieved at the same time, and that, more broadly, both objectives are of merit. But that the realization of one (self-determination) does not depend, legally, on the realization of the other (safeguards for Israel). On this, see the discussion above, text accompanying ng2 above, et seq., and accompanying n2o6 below, et seq.

168 Wilde (2008), above n18, Ch. 8, passim. 
of Nations Mandates system, the UN Trusteeship system, and the UN regime for Non-Self-Governing Territories. Thirdly, it covers occupation by states. Fourthly, it covers International Territorial Administration (ITA) (territorial administration by international organizations, like UNTAET in Timor Leste). These practices were linked to international legal arrangements that set up their termination - and so potentially self-rule by the populations affected in a particular fashion. Termination was to be contingent on certain conditions being met. These conditions concerned standards of governance relating to the populations and territories affected (echoing the security factor raised in this context) and/or the resolution of a dispute (echoing the "outcome of negotiations" factor raised in this context). ${ }^{169}$

However, by the time of the 1967 occupation of the West Bank, this concept of making the end of foreign rule contingent on meeting such conditions had supposedly been repudiated by the external self-determination entitlement, something which was understood in part as a repudiation of the racist civilizational difference between people that underpinned the trusteeship concept itself. ${ }^{170}$ The UNGA adopted resolution 1514 in $1960 .{ }^{171}$ How is it possible, then, that 6 o years after the resolution (regarded as reflective of the position in customary international law at the time) was adopted, the trusteeship basis for ending the occupation, with its racist underpinnings, is still able to predominate within international discussions of the occupation? And be affirmed by the UN, as Ardi Imseis sets out? How can it be that when they address ending the occupation, Orna Ben-Naftali, Aeyal Gross, and Keren Michaeli propose not the immediate transfer of authority to the Palestinian people, but rather a further period of what would presumably be some form of international trusteeship, "pending a comprehensive political solution"? What normative climate has enabled such arguments to remain somehow tenable in mainstream and even ostensibly critical international legal discourse in the supposed "post-colonial," self-determination-era?

\section{Self-Determination Obscured}

This section argues that certain international legal arguments have underpinned the continued legitimation of ideas of trusteeship-over-people in the supposed post-colonial era of self-determination. There is a broad range of

\footnotetext{
$169 \quad I d$.

170 Wilde (2008), above nı, Ch. 8, Section 8.5.

171 G.A. Res. 1514 (XV) (196o), above nı39.
} 
factors at play here, and some are specific to particular situations. ${ }^{172}$ As far as the Palestinian people are concerned, one factor is the aforementioned tendency amongst commentators to bypass the significance of the occupation's legality in use of force terms. Commentators bypass this matter either entirely, or insofar as it is relevant to the question of the existential legitimacy of the occupation - the requirement that it end. Both approaches pave the way for being able to view termination as necessarily contingent on an agreement. This section addresses three additional factors: the effect of the exclusive focus on IHL in general and occupation law in particular; the effect of the concept of "trusteeship;" and the conceptualization of self-determination as a "human right."

The first relevant factor is the exclusive focus on IHL in general and occupation law in particular, legal regimes that are not concerned with the existential legitimacy of the occupation. Their concern is only on how "humane" the conduct of the occupation is. Selectivity in choice of law corresponds to selectivity on substantive-issue-focus. The question of the continued existence of the occupation is off the table, to be determined exclusively as a matter of "politics." Whereas law and politics are not divided in this fashion (e.g., political preferences are embedded in the legal rules regulating the occupation), this particular division is significant for the political role it plays in demarcating what should count when the two matters are addressed. Whereas the conduct of the occupation is a matter of rights, the existence of the occupation is not. Instead, the latter is to be resolved exclusively on a different, pragmatic basis of negotiation. There is, therefore, a different power calculus applicable to the existence of the occupation. This then feeds into and reinforces the idea that "humanitarian" agencies, such as the ICRC and Diakonia, are and should be politically neutral and technocratic. ${ }^{173}$ They can call upon Israel to behave more "humanely" in how it subjugates the Palestinian people - this is a legal requirement. They cannot tell Israel to end the subjugation itself - such matters are exclusively "political."

The exclusive focus on IHL in general and occupation law in particular is also useful in supporting the "trusteeship" basis for ending the occupation only when people are deemed "ready." Its utility here is based on "trusteeship" being

172 For further treatment of different aspects of this general matter, see Wilde (2008), above n18, Ch. 8, Section 8.7, \& Ch. 9, Section 9.2.2.

173 See, e.g., Denise Plattner, ICRC neutrality and neutrality in humanitarian assistance, Int'l Rev. Red Cross 311 (1996), https://www.icrc.org/en/doc/resources/documents/article/ other/57jn2z.htm; and, on Diakonia being "committed to upholding the fundamental principles of humanity and impartiality," Diakonia, Humanitarian Assistance, https:// www.diakonia.se/en/How-we-work/Humanitarian-assistance/. 
the underlying rationale for occupation law, because of the power imbalance between occupier and occupied, and lack of sovereignty enjoyed by the former over the territory of the latter. ${ }^{174}$ Occupation law is introduced supposedly to guarantee that the occupier acts in the interests of the occupied population only, not also its own interests.

This conception of how the relationship between Israel and the Palestinian people is supposed to operate is compatible with the other forms of international trusteeship. Moreover, in those other forms it is accompanied by the further elements, concerning when the arrangements should end, based on

174 In the words of Arnold Wilson: "... enemy territories in the occupation of the armed forces of another country constitute (in the language of Art. 22 of the League of Nations Covenant) a sacred trust, which must be administered as a whole in the interests of both the inhabitants and of the legitimate sovereign or the duly constituted successor in title." Wilson (1932), above n31, at 38. Gerhard von Glahn defines occupation as "... a temporary right of administration on a sort of trusteeship basis ...”. Von Glahn (1995), above n31, at 668. Adam Roberts states that, "... the idea of 'trusteeship' is implicit in all occupation law ... all occupants are in some vague and general sense trustees." Roberts (1985), above n31, at 295 (citing Wilson (above) and von Glahn (above, the same quote contained in an earlier edition)). For Roberts, the law of occupation in both the Hague Regulations and the Geneva Conventions "can be interpreted as putting the occupant in a quasi-trustee role." Id., at 295. Perritt describes the occupations of post-Second World War Germany and Japan, and the CPA occupation of Iraq, as instances of the exercise of trust. See H. Perritt, Structures and Standards for Political Trusteeship, 8 UCLA J. Int'l L. \& Aff. 387 (2003), at 410-16, 422 (general discussion of trusteeship and occupation); at 393-395 (on Germany); 395-396 (on Japan); 407-410 (on Iraq). On the link between the lack of sovereignty, and the trusteeship concept, Gerhard von Glahn conceives occupation on a trusteeship basis on the grounds that "the legitimate government of an occupied territory retains its sovereignty" which is only "suspended in the area for the duration of the belligerent occupation;" Von Glahn (1995), above n31, at 668. In the words of Benvenisti, during the "limited period [of an occupation], the occupant administers the territory on behalf of the sovereign. Thus, the occupant's status is conceived to be that of a trustee," Benvenisti (2012), above n22, at 6 (fn omitted which cites the works by Wilson, von Glahn, and Roberts cited herein (in the case of von Glahn, Benvenisti cites the same quote cited above contained in an earlier edition of the same work)). In 1973, Allan Gerson proposed a concept of "trustee occupation" to be applied to Israel's presence in the Palestinian Territories. The idea was that this would enable the situation under evaluation to be distinguished from occupation generally and, in consequence, certain obligations in the law of occupation. See Gerson (1973), above n31; Gerson (1978), above n76, passim, and in particular at 78-82. This notion that "trusteeship occupation" is somehow a distinct category of occupation is not reflected in the generalized notions of trusteeship adopted by the commentators above in the present footnote. Adam Roberts in particular makes the comments reproduced above in the context of dismissing Gerson's notion, and concludes by expressing skepticism that "trusteeship occupation" is a "separate category of occupation;" Roberts (1985), above n31, at 295 . 
the "ward" people "developing" to the stage when they are "ready" for "selfadministration."175 These additional elements are not part of occupation law, given that it is not concerned with the basis on which occupations end. Nonetheless, the overarching trusteeship link enables approaches echoing those elements, rather than the self-determination approach, to be adopted. Through this, states and the UN can follow the long-standing, wide-ranging adoption of such approaches, running right up to and beyond what happened in Timor Leste at the turn of the 21st century.

According to the normative framework being exclusively followed occupation law - the Palestinian people are treated as passive beneficiaries of what is supposed to be benevolent rule. Viewing the Palestinian people in this way - lacking agency, needing to be "cared" for, only, an approach with clearly gendered, patriarchal characteristics, as Fionnuala Ní Aoláin points out - necessarily places the viability of Palestinian self-administration into question. ${ }^{176}$ This eases the jump to the adoption of the aforementioned trusteeship approaches, independence being rendered dependent on improvements in capacities for self-administration. Put differently, adopting the contrary, self-determination approach of an automatic, immediate right to freedom necessarily requires a sharp rupture from the trusteeship orientation. Indeed, this approach is based on a repudiation of trusteeship over people in and of itself. With an occupation lasting over half a century, the embedding effect on the trusteeship approach potentially enabled by an exclusive focus on occupation law is potentially acute. The rupture required to depart from this is, in consequence, correspondingly acute. One can perhaps see the embedding effect of the occupation-trusteeship worldview in Orna Ben-Naftali, Aeyal Gross, and Keren Michaeli's proposal for ending the Israeli occupation. ${ }^{177}$ They engage in a prolonged treatment of the illegality of the occupation dominated by a consideration of occupation law, including coverage of the "trusteeship" character of this law. When they then turn, at the end of this analysis, to the

175 Wilde (2008), above nı8, Ch. 8, passim, \& in particular Sections 8.3.2 \& 8.3.3 (and sources cited therein).

${ }_{17}$ Indeed, David Kretzmer has characterized the way the Israeli legal system has conceived the relationship between Israel and the Palestinian people under occupation as that of a "benevolent occupant". See David Kretzmer, The Occupation of Justice: The Supreme Court of Israel and the Occupied Territories (2002) (Ch. 4). On the gendered nature of trusteeship, Fionnuala Ní Aoláin observes that its "masculinity ... derives from the inbuilt assumptions of tutelage, infantilization, and patriarchal ordering”. Ní Aoláin (2020), above n31, at 343 .

177 See above text accompanying ni59. 
issue of termination, their proposal is not an immediate end to trusteeship via transfer of control to the Palestinian people. Rather, it is the replacement of trusteeship-occupation by Israel with trusteeship-administration by an "appropriate international authority."178 Ultimately, the only problem seems to be Israel's abusive conduct of the occupation - the breach of trust. Not also trusteeship itself. Trusteeship is valid. Moreover, the Palestinian people will still need it even if the abusive trustee in the form of Israel is removed.

This proposal for a (presumably brief) period of trusteeship by an "appropriate international authority" as an alternative to prolonged, abusive stateconducted trusteeship implies a normative distinction between the two, and a consequent legitimation of the former, echoing ideas I have identified in earlier work. ${ }^{179}$ Trusteeship conducted by international organizations - ITA - has been treated by commentators as normatively legitimate on the basis that, unlike state-conducted trusteeships, the trustee can be relied upon to be selfless and humanitarian. Consequently, trusteeship will be conducted in good faith, not abusively (in both its conduct, and in its application of the test of when local people are "ready" for self-administration). In this way, trusteeship is revived on a now-supposedly-genuinely-temporary basis. And so, the realization of self-determination is modified.

In a different sense, it can be helpful to link state-conducted occupations with ITA and distinguish these practices from state-conducted colonial trusteeship (including under the Mandate and Trusteeship arrangements), to explain another way that the significance of self-determination is obscured when it comes to the former practices. The repudiation of trusteeship-over-people via self-determination in UNGA Resolution 1514 was articulated in general terms ("shall never serve"). However, it was originally affirmed in the colonial context in particular. It is perhaps significant, then, that it is mostly the manifestations of trusteeship-over-people that are not formally designated legally to be "colonial" that have prevailed in the "post-colonial" or, put differently, "post-self-determination-repudiation-of-trusteeship"-era. Describing the stateconducted manifestations of these activities as "occupations" perhaps does the work of obscuring the relevance of self-determination to them. ${ }^{180}$ Indeed,

\footnotetext{
$178 \quad I d$.

179 Wilde (2008), above n18, Ch. 8, section 8.7, especially 8.7.2.3.

180 And, indeed, also describing the international-organization-conducted activities (International Territorial Administration-ITA) as such. For scholars describing ITA as a type of occupation. See, e.g., Steven R. Ratner, Foreign Occupation and International Territorial Administration: The Challenges of Convergence, 16 Eur. J. Int'l L. 695 (2005); Roberts (2006), above n22; Benvenisti (2012), above n22, Preface, Ch. 10; Richard Caplan, International Governance of War-Torn Territories: Rule and Reconstruction 3-4 (2005);
} 
occupation is commonly defined as something which does not cover colonialism, for example where Adam Roberts states that, "[a]t the heart of treaty provisions, court decisions and legal writings about occupations is the image of the armed forces of a state exercising some kind of domination or authority over inhabited territory outside the accepted international frontiers of their State and its dependencies."181 What might be neo-colonial is treated as something other than colonial, for the purposes of the application of self-determination as an existential challenge. Self-determination is posited as only relevant to hangovers from the colonial era and not also of ongoing significance. Accordingly, the only other ongoing relevant aspect of external self-determination is the highly controversial and contested notion of groups within states engaging in secession. ${ }^{182}$ International law regards this type of self-determination to apply only in situations where a group faces an existential threat ("remedial secession") and even here it is of uncertain legal status. ${ }^{183}$ In any case, it is concerned only with groups within the state, not the state and its relations to people outside its territory. This focus on a sub-state group exclusively also takes the attention away from the idea that the people of the state as a whole - like the Iraqi people in 2003 - have the right.

Also significant is how the "post-colonial" state-conducted "occupations" have been normatively disassociated from annexation. In some cases, they were not concerned with it (the occupations of Germany, Austria, Japan, and Iraq, all forms of ITA, certain parts of the oPt). Alternatively, if they were associated with it, this was treated as unlawful in international law (certain parts of the oPt including East Jerusalem [if that is what Israel purports to do there], the Golan, Western Sahara, Timor Leste during the period of Indonesian purported annexation, and Crimea). ${ }^{184}$ The normative disassociation from annexation may further enable the occupations to be disassociated from colonialism (even though some forms of colonialism did not involve the assertion of

Simon Chesterman, You, The People: The United Nations, Transitional Administration, and State-Building (2004) (at 6-7, 11-12, \& 145). For a discussion of how ITA is framed in a way that can obscure the application of self-determination to it, see Wilde (2008), above $\mathrm{n} 18$, Ch. 8, Section 8.7. This is partly the issue identified earlier, concerning the normative identity of international organizations compared to that of states.

181 Roberts (1985), above n31, at 300 (emphasis added).

182 See the sources cited above ni19.

183 Id.

184 But on the US treatment of some of these purported annexations as potentially lawful, see section 7 of this article. On the question of whether Israel has purported to annex East Jerusalem, see above n35. 
sovereignty-as-title over colonial territories). ${ }^{185}$ Thus, labelling a "colony" as an "occupied territory" preserves the colonial concept of trusteeship-over-people, and fends off the application of self-determination. Whereas the designation "occupied territory" brings with it the prohibition of annexation, it does not by itself (in contrast to "colony") involve an obligation that the arrangement be brought speedily to an end through the application of the external self-determination entitlement. Occupiers are supposedly effectively free to end things if and when they see fit, because they are not colonizers, where the rules are different.

The "post-colonial" era, during which certain manifestations of trusteeshipover-people occurred, is significant not only because it is when the seemingly contradictory external self-determination entitlement was adopted. Also, it is when IHRL emerged, and, within this, self-determination was conceptualized as a "human right." This leads to the third way in which international law ideas perpetuated the trusteeship-basis for ending occupations. Here, paradoxically, self-determination has been downgraded in the discourse of the very area of international law - IHRL - within which it was situated.

The humanitarian paradigm shift in the laws of war with the Geneva Conventions can be seen as part of the broader foundation of modern IHRL, starting with the adoption of the UDHR commemorated at the Muwatin conference. The UDHR is part of the so-called "international bill of rights" including the two global human rights covenants. These were followed by a range of instruments dealing with the rights of particular groups and types of rights, many of which Israel and Palestine are parties to. ${ }^{186}$

185 On the issue of title over colonial territories, see, e.g., Crawford (2007), above n124, at 282 et seq; Anghie (2005), above n12, at 82, stating that "[o]nce colonization took place, the colonizing power assumed sovereignty over the non-European territory ..." See also, id., at 82-3. This is also implicit in Crawford's analysis of the effect of the self-determination entitlement on colonial title. Id., at 613-615. On colonial title generally, see, e.g., W.W. Willoughby \& C.G. Fenwick, Types of Restricted Sovereignty and of Colonial Autonomy (1919); M.F. Lindley, The Acquisition and Government of Backward Territory in International Law: Being a Treatise on the Law and Practice Relating to Colonial Expansion (1926); Q. Wright, Mandates Under the League of Nations (1930); D.K. Fieldhouse, Colonialism 1870-1945: An Introduction 16 (1981); Robert Jennings \& Arthur Watts, Oppenheim's International Law. Volume I: Peace $\$ \S 84-85$ (9th ed., 1992); O.C. Okafor, Re-Defining Legitimate Statehood: International Law and State Fragmentation in Africa $20-32$ (2000); Anghie (2005), above nı2 (esp. Chs. 1-4); Anthony Anghie, Finding the Peripheries: Sovereignty and Colonialism in Nineteenth-Century International Law, 40 Harvard Int'l L. J. 1 (1999).

186 For the details of which human rights treaties Israel and Palestine have ratified, see: https://tbinternet.ohchr.org/_layouts/15/TreatyBodyExternal/Treaty.aspx?CountryID=5\& Lang=EN. 
The UDHR does not contain the right to self-determination. It was only with the covenants, adopted in 1966, that the shift in the global normative treatment of colonialism was reflected in IHRL. The right is included, strikingly, as a common provision at the start of both instruments, in article $1 .{ }^{187}$

1. All peoples have the right of self-determination. By virtue of that right they freely determine their political status and freely pursue their economic, social and cultural development.

$[\ldots]$

3. The States Parties to the present Covenant ... shall promote the realization of the right of self-determination, and shall respect that right, in conformity with the provisions of the Charter of the United Nations. ${ }^{188}$

Through this, self-determination, existing already in international law and, as mentioned, the legal basis for formal sovereign-state-based "independence" for peoples subject to colonial rule, was conceptualized as a "human right."189 In General Comment 12 on ICCPR article 1, the UN Human Rights Committee stated that:

Paragraph $3 \ldots$ is particularly important in that it imposes specific obligations on States parties, not only in relation to their own peoples but vis-àvis all peoples which have not been able to exercise or have been deprived of the possibility of exercising their right to self-determination. ${ }^{190}$

187 ICCPR art. 1, above nı19; ICESCR art. 1, above nı19.

188 Id.

189 On self-determination as a human right, see G.A. Res. 1514 (XV) (196o), above nı39, which invokes "fundamental human rights" in its preamble; ICJ Wall Advisory Opinion, above $\mathrm{n} 75$, para. 88 , which refers to common article 1 of the human rights covenants in its treatment of the law of self-determination; Legal Consequences of the Separation of the Chagos Archipelago from Mauritius in 1965, Advisory Opinion, 2019 I.C.J. Rep. 95 (Feb. 25), para. 144 (which describes self-determination is a "fundamental human right"), and para. 154 (which refers to common article 1 of the human rights covenants in its treatment of the law of self-determination); U.N. C.C.P.R., General Comment No. 12: Article 1 (Right to Self-determination), U.N. Doc. HRI/GEN/1/Rev.1 at 12 (1984) [hereinafter General Comment 12]. See also the commentary in Wilde (2008), above n18, at 16o-1 (and sources cited therein).

190 General Comment 12, above n189, para. 6. Jan Klabbers discusses this general comment, criticizing it for seemingly having an "underlying conception" which "appears to be the rather limited one of a legal norm that can only (or predominantly) be implied domestically" (the word "implied" is perhaps a typo, and should be "applied"). Jan Klabbers, The Right to Be Taken Seriously: Self-Determination in International Law, 28 Hum. Rts. Q. 186, 
Israel's obligations in this regard apply to the Palestinian people irrespective of whether they are located in a territory forming part of another state also a party to the Covenant, which the Palestinian people in the West Bank and Gaza were not until Palestine ratified the treaty in 2014:191

The obligations exist irrespective of whether a people entitled to self-determination depends on a State party to the Covenant or not. It follows that all States parties to the Covenant should take positive action to facilitate realization of and respect for the right of peoples to self-determination. ${ }^{192}$

The remainder of the covenants, and all the other human rights treaties applicable to both states, cover rights which have implications for the lives of Palestinian people under the occupation only ${ }^{193}$ (the Arab Charter on Human Rights, which Palestine is a party to, and Israel is not, contains a right of self-determination with provisions directly relevant to the Palestinian people). ${ }^{194}$ Unlike self-determination, these rights do not address the existential legitimacy of the occupation. In this sense, these areas of IHRL operate in the same way as IHL generally/occupation law in particular - as a regulatory system grafted onto the conduct of the occupation.

The UN Human Rights Committee, the body that monitors compliance with and provides authoritative interpretations of the ICCPR, has held that ICCPR article 1 vests a right in only groups, not also individuals. Therefore, an individual cannot claim to be the victim of a violation of the provision for the purposes of bringing an individual complaint (a "communication") to the

198. However, Klabbers is focusing only on para. 4 of the General Comment, which might indeed be characterized in this way.

191 On this ratification, see: https://tbinternet.ohchr.org/_layouts/15/TreatyBodyExternal/ Treaty.aspx?CountryID=5\&Lang=EN. This partly implicates the broader issue, beyond the scope of the present piece, as to whether Palestine is a "state" for the purposes of ratifying the Covenant. On this issue, see above ni35.

192 General Comment 12, above n189, para. 6.

193 The African Charter of Human and Peoples' Rights, which, obviously, the two states are not a party to, includes a right of self-determination (Art. 20.1). See African Charter on Human and Peoples' Rights, O.A.U. Doc. CAB/LEG/67/3 rev. 5 (1981).

194 Arab Charter on Human Rights art. 2 (reprinted in 12 I.H.R.R. 893 (2005) (2004) (see, in particular, paras. 3 \& 4). On Palestine being a party, see Mervat Rishmawi, The League of Arab States: Human Rights Standards and Mechanisms, Open Society Foundations, Cairo Institute for Human Rights (2015). 
committee. ${ }^{195}$ This is not directly relevant to Israel - Israel has not accepted the right of individual complaints to the committee under Optional Protocol 1 to the ICCPR. ${ }^{196}$ But the general effect of the committee's position, combined with the absence of the right of self-determination in the American and European regional instruments, is as follows. Most of the generators of jurisprudence on the meaning and scope of human rights treaty law - decisions associated with individual communications or complaints/cases to the committee and the American and European enforcement bodies - has produced what is now a dense field of law in which self-determination is largely absent. ${ }^{197}$ When that is considered alongside the body of human rights treaty law, where self-determination is included only in two potentially globally-applicable treaties, the result is a normative mass conceiving IHRL as a regulatory regime grafted onto the conduct of state authority, whether territorially or extraterritorially. And not also a body of law that can, in certain circumstances, place the legitimacy of the existence of that authority into question.

It might have been thought that although the UN Human Rights Committee seems to have excluded considering self-determination through individual communications, it would take the opportunity to address the right through the state reporting system. Indeed, in General Comment 12, the UN Human Rights Committee stated that: "The reports should contain information on the performance of these obligations and the measures taken to that end."198

However, for this body, and the other committee operating under the ICESCR, in their concluding observations on Israel, and the related lists of issues they ask that state to take up, the opportunity has been largely missed. When addressing the situation of the Palestinian people in the oPt, the few references to article 1 and the right to self-determination are all made in relation to second-order issues (e.g., the expansion of settlements, freedom of

195 In the words of the Committee, “... the Committee observed that the author, as an individual, could not claim to be the victim of a violation of the right of self-determination enshrined in article 1 of the Covenant. Whereas the Optional Protocol provides a recourse procedure for individuals claiming that their rights have been violated, article 1 of the Covenant deals with rights conferred upon peoples, as such." Ivan Kitok v. Sweden, U.N. Doc. CCPR/C/33/D/197/1985 (July 27, 1988), para. 6.3.

196 See the website cited above nig1.

197 See, e.g., the databases of decisions available at: https://juris.ohchr.org/; http://www.oas .org/en/topics/human_rights.asp; http://echr.coe.int/echr/en/hudoc; https://www.achpr .org; http://wwwl.umn.edu/humanrts/africa/comcases/allcases.html; and the works listed in OUP HR list (2017), above n8; and Robert McCorquodale, Self-Determination: A Human Rights Approach, 43 Int'l \& Comp. L. Q. 857, 871-872 (1994).

198 General Comment 12, above n189, para. 6. 
movement etc.). ${ }^{199}$ The "external" right to be free of the occupation itself is ignored. Thus, for example, the committees address land expropriation only on an individual level, and only in terms of the impact on the rights of the individuals affected. Yet Israel potentially "expropriates" land also on a collective level, as in the case of the purported annexation of East Jerusalem, which, if the case, involves an effort by the state of Israel to take land from

199 C.E.S.C.R., List of issues to be taken up in connection with the consideration of the second periodic report of Israel, U.N. Doc. E/C.12/Q/ISR/2 (June 5, 2002), para. 1; C.E.S.C.R., List of issues to be taken up in connection with the consideration of the third periodic report of Israel, U.N. Doc E/C.12/ISR/Q/3 (Dec. 9, 2010), para. 3 [hereinafter CESCR (2010)]; C.E.S.C.R., Concluding Observations of the Committee on Economic, Social and Cultural Rights: Israel, U.N. Doc. E/C.12/1/Add.27 (Dec. 4, 1998), paras. 11 \& 16-17 [hereinafter CESCR (1998)]; C.C.P.R., Concluding Observations of the Human Rights Committee: Israel, U.N. Doc. CCPR/C/ISR/CO/3 (Sep. 3, 2010), paras. 8 \& 16 [hereinafter CCPR (2010)]; C.C.P.R., Concluding observations of the Human Rights Committee: Israel, U.N. Doc. C/ ISR/CO/4 (Nov. 21, 2019), paras. 12 \& 17 [hereinafter CCPR (2019)]; C.C.P.R., List of issues to be taken up in connection with the consideration of the Third periodic report of Israel, U.N. Doc. CCPR/C/ISR/Q/3 (Nov. 17, 2009), para. 3 [hereinafter CCPR (2009)]; C.C.P.R., List of issues prior to the submission of the fourth periodic report of Israel, U.N. Doc. C/ISR/Q/4 (Aug. 31, 2002), paras. 1, 8, \& 18-19 [hereinafter CCPR (2012)]; C.C.P.R., List of issues prior to submission of the fifth periodic report of Israel, U.N. Doc. C/ISR/Q/PR/5 (Sep. 7, 2018), paras. 6, 8, \& 18-19 [hereinafter CCPR (2018)]. Israel has refuted the applicability of the Covenants to it as far as the oPt are concerned, which has implications for its willingness to report on the situation there to the committees. But both committees have rejected this position on applicability, and have, indeed, addressed the situation of the Palestinian people in the oPt. See C.C.P.R., Concluding observations of the Human Rights Committee: Israel, U.N. Doc. CCPR/C/79/Add.93 (Aug. 18, 1998), para. 10 [hereinafter CCPR (1998)]; C.C.P.R., Concluding observations of the Human Rights Committee: Israel, U.N. Doc. CCPR/CO/78/ISR (Aug. 21, 2003), para. 11; CCPR (2010), id., para. 5; CCPR (2019), id., para. 5; CCPR (2012), id., para. 4. On the position under the ICESCR, see also CESCR (1998), id., paras. 7-8; C.E.S.C.R., Concluding Observations of the Committee on Economic, Social and Cultural Rights: Israel, U.N. Doc. E/C.12/1/Add.69 (Aug. 13-31, 2001), para. 11 [hereinafter CESCR (2001)]; C.E.S.C.R., Concluding Observations of the Committee on Economic, Social and Cultural Rights: Israel, U.N. Doc. E/C.12/1/Add.9o (June 26, 2003), para. 31 [hereinafter CESCR (2003)]; C.E.S.C.R., Concluding Observations of the Committee on Economic, Social and Cultural Rights: Israel, U.N. Doc. E/C.12/ISR/CO/3 (Dec. 16, 2011), para. 8 [hereinafter CESCR (2011)]; C.E.S.C.R., Concluding Observations of the Committee on Economic, Social and Cultural Rights: Israel, U.N. Doc. E/C.12/ISR/ $\mathrm{CO} / 4$ (Nov. 12, 2019), paras. 9, 11 [hereinafter CESCR (2019)]. On this issue, see also Wilde (2018), above n28; and, for the position under the ICESCR, Ralph Wilde, Pursuing Global Socio-Economic, Colonial and Environmental Justice through Economic Redistribution: The Potential Significance of Human Rights Treaty Obligations, in Research Handbook on International Law and Social Rights 81-82 (C. Binder, et al. eds., 2020) (and sources cited therein). For two examples of other practice of the committee in relation to Palestinian self-determination in the context of reporting relating to Italy and Jordan, see D McGoldrick, The Human Rights Committee 251 (1994); sources cited in n56. 
the Palestinian people as a whole. ${ }^{200}$ Such purported annexation necessarily constitutes a violation of collective self-determination. Despite this, whether it is happening/has happened, and the legal consequences of this in the law of self-determination, are not addressed. On the one hand, the UN Human Rights Committee refuses to address self-determination on an individual level in individual complaints. On the other hand, when the collective dimension of the right is violated, this is overlooked in favor of an exclusive focus on the individual dimension in country reporting. Either way, then, the more fundamental questions of violations of the collective right of self-determination are not addressed.

The closest things get is when both committees call for the blockade of Gaza to be lifted, the UN Human Rights Committee invoking article 1 (and other articles) in this context. ${ }^{201}$ However, these calls are made only in the context of the humanitarian consequences of the blockade. Indeed, when the UN Human Rights Committee makes its call, the call itself is tied to that specific issue. It states that Israel "should lift its military blockade of the Gaza Strip, insofar as it adversely affects the civilian population." ${ }^{202}$ The notion that the blockade might also constitute a more fundamental denial of self-sustaining autonomous freedom, which implicates external self-determination, and that this should also be the basis for it to be lifted, is not addressed.

With exception of General Comment 12 of the UN Human Rights Committee, the main contributions to the jurisprudence of self-determination as a "human right," both its meaning and its application to particular situations, have come from a generalist international law court operating outside the human rights-specific system. This is the ICJ in the Wall and Chagos Advisory Opinions. ${ }^{203}$ In the former opinion, the ICJ addressed the legal consequences of the construction of the Wall by Israel in the oPt, holding this to be violation of, inter alia, self-determination. ${ }^{204}$ It expressly invoked the articulation of self-determination in IHRL. ${ }^{205}$ Presumably because of the limitations of the question put to the ICJ by the UNGA, it did not opine on the legitimacy of the occupation per se, on any basis, including in self-determination terms. However, at the end of the Opinion, it stated that:

\footnotetext{
200 On Jerusalem, including the issue of purported annexation, see the sources cited above n35.

201 CESCR (2011), above n199, para. 8; CESCR (2019), above n199, para. 11. See also CCPR (2019), above n199, para. 19; CCPR (2012), above n199, para. 19.

202 CCPR (2010), above nig9, para. 8.

203 See the quotations and associated citations above n189.

204 Id.

205 Id.
} 
The Court considers that it has a duty to draw the attention of the General Assembly ... to the need for ... efforts to be encouraged with a view to achieving as soon as possible, on the basis of international law, a negotiated solution to the outstanding problems and the establishment of a Palestinian State, existing side by side with Israel. ${ }^{206}$

This is notable because it postulates two objectives, an agreement ("negotiated solution to the outstanding problems"), and the need for a Palestinian state to be established (which can be understood as the realization of self-determination), without also, as in some of the other approaches reviewed above, suggesting that the former is a prerequisite for the latter. ${ }^{207}$ The requirement that Israel needs to "agree" to the realization of Palestinian statehood is also implicitly ruled out by the ICJ prefacing the achievement of the two objectives as needing to be "on the basis of international law."

When it was asked a broader question encompassing the equivalent matter in the case of the legitimacy of the UK authority over the Chagos Archipelago, the ICJ in the latter Opinion took the step on the question of ending such authority that was absent from the former Opinion. It applied what it now referred to as a "fundamental human right" of self-determination to find that the continued UK administration was unlawful, and the UK had an obligation "to bring an end to its administration as rapidly as possible."208 There is no mention that such an end should come after an agreement, and/or when the population whose return it might enable are deemed "ready." The requirement is "as rapidly as possible."

That a generalist court could make a greater contribution to the law on self-determination as a human right than human rights bodies is perhaps not just an inevitable consequence of the marginalized treatment of the topic by such bodies. ${ }^{209}$ These two related developments may reflect a significant syndrome within each set of actors which operates in a mutually reinforcing fashion.

206 ICJ Wall Advisory Opinion, above n75, at 162.

207 For these approaches, see above text accompanying n156 et seq, \& Section 6. For a reading of the meaning of UNSC Resolution 242 consonant with the ICJ approach, see above nıo. See also above n167.

208 ICJ Chagos Advisory Opinion, above n189, paras. 144, 174, \& 177-8.

209 For further analysis on the related subject of contribution made by the ICJ to jurisprudence on the extraterritorial application of IHRL generally, see Ralph Wilde, Human Rights Beyond Borders at the World Court: The Significance of the International Court of Justice's Jurisprudence on the Extraterritorial Application of International Human Rights Law Treaties, 12 Chinese J. Int'l L. 639 (2013). 
On the one hand, human rights experts and expert bodies may be uncomfortable straying into a topic requiring them to move outside their specialism to take in general public international law. This may be especially the case on a subject that even by the standards of human rights is contested and controversial. It concerns not simply whether particular state practices are lawful (which they normally consider), but whether the very exercise of state authority in a given territorial area is itself lawful. Moreover, in order to determine the legality of the existence of the occupation, it would be necessary to account for not only the law on self-determination, but also the law on the use of force. The particular area of international law they would have to move into is of the most fundamental character in the field. ${ }^{210}$

On the other hand, and by contrast, ranging across different areas of international law (including the law on the use of force), and addressing such existential questions, is the normal business of the ICJ. The approach taken by human rights experts and expert bodies may also reflect the idea that the relevance of external self-determination in the post-colonial era is exclusively about groups within states, not also when states dominate groups outside their sovereign territories. Since the former category of the concept is regarded to be of somewhat uncertain legal standing (certainly when it comes to its secessionary consequences), the overall topic can itself sometimes appear to be of an extra-legal character: non-justiciable and exclusively political.

Whatever the cause, there is not a rich jurisprudence on external selfdetermination by human rights bodies that Palestinian people can draw on when seeking to invoke the human right to self-determination to frame their assertion of freedom. And they cannot currently expect the support of international human rights NGOs either. These organizations, such as Amnesty International and Human Rights Watch, have not generally concerned themselves with external self-determination, or called for an end to the occupation on this or any other basis, when it comes to Palestine. ${ }^{211}$ It will be recalled that Amnesty International UK asks for support in order to "help end the 50 year oppression of the Palestinians". ${ }^{212}$ But it then articulates its objective in this regard "to end the human rights abuses suffered by Palestinians under the

\footnotetext{
210 The potential for this is explored further below, text accompanying n23o, et seq.

211 See Amnesty International, Israel and the Occupied Palestinian Territories Amnesty International (2019) [hereinafter Amnesty International (2019)], https://www.amnesty .org/en/location/middle-east-and-north-africa/israel-and-occupied-palestinian-territo ries/report-israel-and-occupied-palestinian-territories/; Human Rights Watch, Israel and Palestine Events of 2019 (2019) [hereinafter Human Rights Watch (2019)], https://www.hrw .org/world-report/202o/country-chapters/israel/palestine.

212 Amnesty International UK (2019), above nio.
} 
Israeli occupation," not also to end the occupation itself. ${ }^{213}$ In a complementary move, the self-determination-omitting UDHR is posited as the "bedrock of all" Amnesty's campaigning, as "the most concerted effort to date to bring together all fundamental rights, and is used as the basis for all international human rights law."214 This all fits perfectly for an account of IHRL that focuses exclusively on those areas of this law regulating the treatment of individuals under a state's authority, whilst ignoring the right regulating the legitimacy of the exercise of authority itself. In this way, the "tools" of IHRL are concerned with making conditions for life as part of the master's house better, not dismantling the house - the conditions of oppression - itself. In a gaslighting move, this is placed under the bold, dissimulating banner of efforts to "end" the "oppression of Palestinians".

Here there is symmetry with the aforementioned limited IHL/occupation law focus. For the two human rights committees, and two leading international human rights NGOs, IHRL only means rendering the occupation supposedly more humane, not also ending it. What is striking about adopting the exclusively regulatory approach from IHL in IHRL is that, unlike the former, the latter does actually include a clear existential challenge to the occupation. It was observed earlier that it is necessary to depart from the worldview of IHL and occupation law to challenge the existence of the occupation. It would also seem to be necessary to depart from the worldview of human rights - at least as presently understood by the two human rights committees and two leading international human rights NGOs - to advocate for self-determination, both generally, and as an entitlement in IHRL.

IHRL experts, committees and NGOs encourage oppressed people around the world to use the language of IHRL to articulate their demands. But if they do this, and the demand in question is liberation, and the language they use is self-determination, will these experts, and the institutions of IHRL, listen?

The foregoing is predicated on a concept of Palestinian external self-determination within the non-Israeli boundaries of the remainder of Mandatory Palestine, because of the prior acceptance of Israeli statehood as a given. Since Israel's IHRL obligations concerning self-determination apply not only externally, but also internally, there are also implications for Palestinian people within the state.

The UNGA affirmed in 1948 the right of return to Palestinian people displaced from what became Israel in $1948 .{ }^{215}$ This has been repeated by that body

\footnotetext{
213 Id.

214 Amnesty International UK (2018) above n9.

215 See, e.g., G.A. Res. 194 (III) (Dec. 11, 1948); Kathleen Lawand, The Right to Return of Palestinians in International Law, 8 Int'l J. Refugee L. 532 (1996); Yahia (1970), above n16,
} 
numerous times since. Such a right would be the basis for the Jahalin to return to al-Naqab. However, the UN Human Rights Committee has never addressed the right of Palestinian people outside Israel to return there, or, even, the rights of Palestinian people outside the oPt to return to those territories. The only treatment of the return topic, a statement relating to what it calls "the right to return to one's own country," is in the context of the movement of Palestinian people between Gaza, East Jerusalem and the West Bank. ${ }^{216}$ This is only "return" in the sense that Palestinian people have to leave Palestine (defined as the oPt) and "return" to it to get between the West Bank and Gaza. And even this doesn't happen when Palestinian people move between East Jerusalem and the rest of the West Bank - it is "returning" to a different location within, not returning to from outside, the "country" (unless Israel is regarded as having lawfully annexed East Jerusalem ...). Thus, the UN Human Rights Committee invokes a "right to return," only to define it in a manner that is distorted for its own purposes and excludes entirely the issue the term is usually invoked to address. Under this approach, the right to so-called "return" of the Jahalin is a right to move between the place they were displaced to in East Jerusalem, and Gaza, if they happen to wish to visit Gaza, and back again. There is no right to return to the place they were displaced from.

The UN Committee on Economic, Social and Cultural Rights (CESCR) has addressed the issue of return to Israel thus:

The Committee notes with concern that the [Israeli] Law of Return, which allows any Jew from anywhere in the world to immigrate and thereby virtually automatically enjoy residence and obtain citizenship in Israel, discriminates against Palestinians in the diaspora upon whom the Government of Israel has imposed restrictive requirements which make it almost impossible to return to their land of birth. ${ }^{217}$

Thus, concerns about "return" are limited to restrictions on migration to Israel that are discriminatory as between Jewish and Palestinian people. Presumably, if Israel halted further inward migration, the concerns would fall away. As would any Palestinian right to return. The statement also implicitly treats the issue of the return of Palestinian people who were displaced from the place they would return to, as equivalent to the ability of all Jewish

at 106-115; Albanese \& Takkenberg (2020), above n38, at 342-375 (and sources cited therein); Terry Rempel, The Right to Return: Drafting Paragraph 11 of General Assembly Resolution 194 (III), December 11, 1948, 21 Palestine Y.B. Int'l L. 78 (2020).

216 CCPR (1998), above ni99, para. 22.

217 CESCR (1998), above n199, para. 13. See also CESCR (2001), above n199, para. 14; and CESCR (2003), above nig9, para. 18. 
people from anywhere in the world to perform Aliyah, regardless of any prior similar direct past personal experience of displacement from the territory which has since 1948 been Israel. For the committee, the merit of Amran Reshaq's wish to return to the land of his birth has no significance by itself. It is only to be appraised when compared to the possibilities that exist for Jewish people generally, regardless of an equivalent place-of-birth-connection, to migrate to Israel.

Otherwise, the only focus has been on return within Israel, i.e. of Palestinian citizens of Israel who were internally-displaced (irrelevant to the Jahalin and to many other Palestinian refugees). Only the CESCR has addressed this. ${ }^{218}$ The UN Human Rights Committee has been silent, just as it has been on return to Israel. The CESCR has partially conceptualized its focus on internal return under article 1 . This reflects the position both committees, and also Amnesty International, took in invoking Palestinian self-determination in the context of the enjoyment of this right as citizens of Israel when considering the 2018 Israeli nation-state law. That law defines Israel as the "Nation State of the Jewish People." In this context, they expressed concerns about (the CESCR), asked questions about (the UN Human Rights Committee), criticized (Amnesty) the law for its (potentially, for the committees) discriminatory effect on non-Jewish people in Israel when it comes to their enjoyment of, inter alia, their right to self-determination. ${ }^{219}$ For the committees, this comes in the context of the aforementioned exclusive focus on second-order aspects of self-determination for the Palestinian people. For Amnesty, this is the only instance where any form of self-determination is referenced at all. ${ }^{220}$ Seemingly, this right is only relevant to the human rights situation across Israel and the oPt insofar as Israeli citizens within the Israeli state are concerned. The only issue of Palestinian self-determination Amnesty is concerned with is the status of Palestinian citizens of Israel.

Moreover, the pejorative description of the nation state law as (potentially) discriminatory with respect to the enjoyment of self-determination implies that the self-determination unit of the people of Israel, in which equal

218 CESCR (1998), above n199, para. 25; CESCR (2010), above n199, para. 3.

219 CESCR (2019), above n199, paras. 16-17 \& 68; CCPR (2012), above n199, para. 1; C.E.S.C.R., List of issues in relation to the fourth periodic report of Israel, U.N. Doc. E/C.12/ISR/Q/4 (Apr. 3, 2019), paras. 11-12 \& 25 [hereinafter CESCR (2019)b]; CCPR (2018), above n199, para. 6. See also the determinations on prior iterations of the Basic Law, in CCPR (2010), above n199, para. 6; C.C.P.R., Concluding observations of the Human Rights Committee: Israel, U.N. Doc. CCPR/C/ISR/CO/4 (Nov. 21, 2014), para. 7 [hereinafter CCPR (2014)]; CCPR (2009), above nig9, para. 2; CCPR (2012), above n199, para. 5 .

220 Amnesty International (2019), above n211. 
participation is being (potentially) denied, is legitimate. Otherwise, the denial would not be problematic. Implicitly, the right of self-determination of the people of the state of Israel is affirmed as legitimate. Thus, an approach which is ostensibly not concerned with such existential matters as whether or not a particular group has a right of self-determination - hence the absence of any concern for (Amnesty) or very partial treatment of (the two UN committees) Palestinian self-determination - ends up in such terrain, but only as far as Israeli self-determination is concerned. What is supposedly about Palestinian rights - not to be discriminated against - ends up being doubly objectionable. First, it ignores the right of Palestinian collective self-determination, whether entirely (Amnesty) or for the most part (the committees). Second, this neglect occurs in the context of an affirmation of the right of self-determination of the people of the very state whose actions in a different (but related) context are preventing Palestinian self-determination from being realized. Put differently, an effort to combat discrimination against Palestinian people relative to treatment of Jewish people within Israel actually discriminates against them relative to the treatment of Jewish people. And it does so on the more relevant matter of their right to self-determination as part of a collective Palestinian identity rather than as citizens of Israel. Invoking discrimination in this context is particularly, ironically egregious given how racism underpins the concept of trusteeship that operates as the alibi for denying self-determination to the Palestinian people. An ostensibly 'anti-discrimination' critique thus serves racist ends.

\section{Erosion of Legal Standards?}

The analysis in sections 3 and 4 indicates how the application of the international law on the use of force, and self-determination, leads to the position that the occupation should end, and Israel's purported annexation of Palestinian territory, whether existent (e.g., potentially, East Jerusalem) or prospective, is/would be without legal effect. Sections 5 and 6 illustrate how, despite this, occupations have sometimes been prolonged, and de facto annexations are not subjected to much effective criticism, in part because the significance of self-determination has been downgraded and even overlooked entirely.

All of this presupposes that the legal framework is as sections 3 and 4 describe. And it assumes, in consequence, that the practice under evaluation and the reactions to it by other states indicates a situation of prolonged legal violation and a failure by other states to stop this. But there is a different possibility: that this practice and the responses to it by states might somehow have 
effected, or might be in the process of effecting, a normative shift. Are the rules being altered to accommodate that which had previously been prohibited?221

Writing in 1963 about the prohibition on annexation through the use of force, Robbie Jennings suggested that in a situation where the law on the use of force has not been enforced, in the sense that a state controlling territory unlawfully has not been made by the "international community" to withdraw,

it may eventually come about that a title by consolidation is acquired through recognitions or other forms of the position expressive of the will of the international community. On the other hand the general reaction of third states may be to adopt an attitude of non-recognition; and in these circumstances it seems illogical to suppose that any form of prescription even by adverse possession could begin to run. ${ }^{222}$

Jennings made the foregoing remark in the context of a situation where a state has "successfully seized possession of territory by illegal force and seems likely to stay."223 It would apply a fortiori if, as here, the "stay" has been prolonged and sustained through an unlawful use of force. According to this possibility, whereas an unlawful occupation could not by itself found valid title, the taint caused by being based on the use of force could be remedied through recognition by other states.

Jennings speculates about this possibility, presumably, on the basis of an orthodox, positivist approach to international law. Rules are made by states, and states can change these rules through practice ("expressive of the will of the international community"). The very existence, or at least the application in particular instances, of the international legal protections against force-enabled annexation are, therefore, potentially precariously linked to the position states take. One might also ask whether this idea could also operate to encompass the law on self-determination and its significance to the prohibition on annexation. And also how this law, and the law on the use of force, prohibit the prolonged occupation.

States individually and through the UN have mostly taken the position that the Palestinian territories, including East Jerusalem, are "occupied." This presupposes non-recognition of any annexation, whether generally or specifically

221 For a discussion of this general topic when it comes to Israeli and US policy, with a predominant focus on IHL rules, see George Bisharat, Violence's Law Israel's Campaign to Transform International Legal Norms, 43 J. Palestine Stud. 68 (2013).

222 Jennings (1963/2017), above n76, 2017 reprint version, at 84. See also id., at 78-82.

$223 I d$., at 84. 
as far as East Jerusalem is concerned (if relevant). ${ }^{224}$ But it seems the US position has shifted, both in relation to Jerusalem, potentially, with the relocation of the US embassy there from Tel Aviv in 2019, and other parts of the West Bank covered by President Trump's "deal of the century" in 2020. ${ }^{225}$ Furthermore, the Trump administration recognized Israeli sovereignty over the Golan heights, and Morocco's sovereignty over Western Sahara. ${ }^{226}$ The Golan recognition defies the prohibition of annexation through the use of force. The two recognitions defy the invalidity of claims to title over territory when another state is sovereign over that territory (Syria in the Golan) or the territory is a non-state self-determination unit where "sovereignty" resides in the people (Western Sahara). The US position on the non-East-Jerusalem parts of the West Bank covered by the "deal of the century" may shift in the post-Trump era. But when it comes to the embassy in Jerusalem, the Biden Administration stated it would not move back to Tel Aviv, and the new US Senate in 2021 voted to affirm funding for the embassy in its Jerusalem location. ${ }^{27}$ At the time of writing, President Biden had not shifted the US position on sovereignty over the Golan or Western Sahara (although on the former, his Secretary of State seemed to indicate the matter was to be reviewed). ${ }^{228}$

224 See, e.g., Roberts (1990), above n31, at 69 (and sources cited therein). On the question of whether Israel has purported to annex East Jerusalem, see above n35.

225 A treatment of the nature of the US position on Jerusalem, both prior to and with the relocation of the embassy in 2019, and the prospects of Israeli annexations based on the "deal of the century," are beyond the scope of the present piece.

226 On the recognition re the Golan heights, see Donald J.Trump, Proclamation on Recognizing the Golan Heights as Part of the State of Israel, Trump White House Archives (Mar. 25, 2019), https://trumpwhitehouse.archives.gov/presidential-actions/proclamation-recogni zing-golan-heights-part-state-israel/; Hoffman (2020), above n19, para. 33; United States Recognizes Israeli Sovereignty Over the Golan Heights, 113 Am. J. Int'l L. 613 (2019). On the recognition re Western Sahara, see Trump White House Archives (2020), above n154.

227 See Biden says he'd leave US embassy in Jerusalem if elected, Al Jazeera (Apr. 29, 2020), https://www.aljazeera.com/news/2020/4/29/biden-says-hed-leave-us-embassy-in-jeru salem-if-elected; Roll Call Vote 117th Congress - 1st Session: To establish a deficit-neutral reserve fund relating to maintaining the United States Embassy in Jerusalem, Israel, United States Senate (Feb. 4, 2021), https://www.senate.gov/legislative/LIS/roll_call_lists/roll_call _vote_cfm.cfm?congress $=117 \&$ session $=1 \&$ vote $=00030 ;$ US to keep embassy in Jerusalem: Biden's top diplomat, Al Jazeera (Jan. 20, 2021), https://www.aljazeera.com/news/2021/1/ 2o/us-secretary-of-state-blinken-us-embassy-to-remain-in-jerusalem.

228 On US Secretary of State position on the Golan, see, e.g., Jacob Magid, Blinken supports Israel holding Golan, but backs off recognizing sovereignty, Times of Israel (Feb. 9, 2021), https://www.timesofisrael.com/blinken-supports-israel-holding-golan-but-backs-off -recognizing-sovereignty/. On the Western Sahara, 27 US Senators wrote to President Biden in January 2021 calling on him to reverse the recognition of Moroccan sovereignty 
This practice suggests that the possibilities outlined by Jennings have to be considered seriously. Whether the substantive rules of international law can be and are in the process of being altered is beyond the scope of this article. Jennings wrote in 1963 and does not account for the law of external self-determination, which was still in the process of being widely acknowledged to exist at that time. Further developments, to treat prohibitions on the use of force, and obligations to respect self-determination, as having jus cogens status (mentioned above in relation to other obligations), and the latter as having erga omnes status, were also yet to happen. ${ }^{229}$ These developments implicate whether and on what basis state practice could water down the prohibitions (jus cogens) and also, relatedly, the legal consequences of any state practice incompatible with these prohibitions (erga omnes). Moreover, the US is an outlier in its position on the Golan, East Jerusalem, and Western Sahara.

Nonetheless, it is not a huge leap from the position adopted by the two UN human rights committees and leading human rights NGOs, which fails to characterize the continued occupation as a violation of self-determination, to a position that positively affirms the occupation as not such a violation (indeed, as not an occupation at all). Creating a bigger space between their position and the latter position might negatively impact the prospects of the latter position taking hold. Those seeking to hold the line on the current legal standpoint on the right of Palestinian self-determination, when this is under threat, need to consider the normative consequences of their silence on the question of the significance of this right to ending the occupation.

In General Comment 36 of 2018, on the right to life under article 6 of the ICCPR, the UN Human Rights Committee made the remarkable statement that "states parties engaged in acts of aggression as defined in international law, resulting in deprivation of life, violate ipso facto article 6."230 This potentially constitutes an expression of willingness to address the implications of the law on the use of force for one of the rights under the covenant. The committee seemingly crossing this Rubicon when it comes to the right to life sets a precedent for it and the CESCR to assess the legality of the continued

by President Trump; see: https://www.inhofe.senate.gov/newsroom/press-releases/ inhofe-leahy-lead-25-colleagues-to-urge-biden-to-reverse-misguided-western-sahara -decision.

229 On jus cogens, see the sources cited above n115. The prohibition of aggression, and the right of self-determination, are included as further examples ((a) and (h)) on the ILC list cited above in that note. On self-determination as having erga omnes status, see the sources cited in nu19 above.

230 C.C.P.R., General comment No. 36 (2018) on article 6 of the International Covenant on Civil and Political Rights, on the right to life, U.N. Doc. CCPR/C/GC/36 (Oct. 30, 2018), para. 70. 
occupation according to the right to self-determination and the law on the use of force. Whether they, and human rights NGOs, step up to this challenge and thereby begin to engage with Palestinian claims to end the occupation remains to be seen.

\section{Conclusion}

What does it mean when the tools of a racist patriarchy are used to examine the fruits of that same patriarchy? It means that only the most narrow parameters of change are possible and allowable.

AUDRE LORDE ${ }^{231}$

When general areas of international law are invoked to address the needs of the Palestinian people, this is typically done in an uncritical fashion. The present article has attempted to complicate the picture, suggesting some of the downsides to these legal frameworks in how they relate to the existential question of Palestinian liberation.

In certain important respects, the starting point for international law on this subject is to accept Israeli statehood as a given. In consequence, Palestinian freedom must fit around and/or be articulated in relation to Israel's needs. The territory covered by the right of self-determination is that which is "left" of the territory of the Palestine Mandate once Israel is taken into account. ${ }^{232}$ Occupation law, the international legal framework commonly invoked, is concerned not with ending the occupation, but with merely "humanizing" it within an overall framework of domination. Even to invoke these standards, it is necessary to recognize Israel's statehood. And this has to be done when it is statehood that is the very thing that the occupation prevents the Palestinian people from realizing effectively. And, moreover, it has to be done despite the fact that it is this statehood on the part of Israel that was created through and continues to operate on the basis of the Nakba, with the consequent position

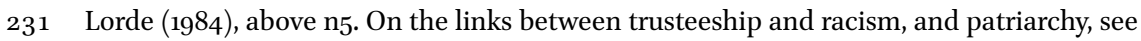
above, text accompanying n168 \& n17o (racism) and n176 (patriarchy). On the problematic invocation of discrimination by certain human rights bodies, see above, the final paragraph of Section 6. On gender and occupation more generally, see Ní Aoláin (2020), above n31.

232 This reflects the establishment view held by international law experts. But see earlier for the challenge that can be made to it, above n128. Moreover, in any case the position on Jerusalem is more complicated, and, certainly, East Jerusalem is not "Israel" for the purpose of this analysis. 
of many Palestinian people as refugees, and the treatment of Palestinian people within Israel as second-class citizens.

Taken together, the law on the use of force and the law of self-determination offer a basis for challenging the legitimacy of the continued existence of the occupation. This can pave the way for the limited version of freedom international law offers to the Palestinian people: statehood in a territory outside the green-line-defined borders of Israel. It also renders unlawful Israeli annexation of that territory, including (if this is what Israel has purported to do) East Jerusalem. But sometimes commentators are fixated on the prohibition of annexation only, without also addressing the ending of the occupation. To make the argument on the latter point requires a move beyond the exclusive annexation-prohibition-fixation, and its partner, the occupation-law fixation. Moreover, Palestinian people are required to counter a further idée fixe: the commentariat's predominant approach, and also significant practice within the UN, that Palestinian self-determination should only be realized once there is a peace agreement with Israel. One can challenge this approach, making the case for an immediate end to the occupation by applying the law on the use of force, which is the only basis on which Israel can lawfully maintain the occupation. This leads to the conclusion that the occupation is illegal and constitutes aggression. However, most experts fail to address this area of law, thus making it more difficult to appreciate the significance of it, let alone to invoke and apply it. This enables the "wait for an agreement" alternative to have purchase as an operative norm. Moreover, making the challenge requires an assessment through a framework exclusively concerned with the question of Israel's security needs. Using the law's "tools," therefore, requires Palestinian people to frame their case for liberation not in terms of their perspective at all, but rather in terms of the illegitimacy of Israel's position.

Furthermore, it is difficult to make the self-determination element of the challenge. This is in part because of the way IHRL jurisprudence downgrades and sometimes even completely ignores the significance of the right's external dimension. Such an approach is evident in the practice and statements of the two main international expert committees charged with monitoring the implementation of IHRL, and two leading international human rights NGOs. Just as with the exclusive occupation law-focus, these bodies address second-order issues only without also considering whether the occupation is, in and of itself, a violation of self-determination. It is as if the Palestinian right to external self-determination does not exist. Moreover, paradoxically, when these bodies have addressed the rights of Palestinian citizens of Israel, this has partly included coverage of their right to participate in the collective 
self-determination unit of that state. Thus, Palestinian self-determination gains attention, but only indirectly, via participation in and as part of the collective self-determination unit of the Israeli people. This brings things full circle, back to the starting point: Israeli statehood and the legal consequences that follow from its recognition (in this case, Israeli statehood as the external instantiation of the collective self-determination right of the people of that state.)

Finally, even these remarkably limited approaches are themselves based on legal concepts - external self-determination and the prohibition on annexation through the use of force - which have been placed under strain by the Trump administration's recognitions in relation to Israel and the Golan, Morocco and Western Sahara, and the moving of the US embassy in Israel to Jerusalem (maintained by the Biden administration). There has been a degree of handwringing by international lawyers about this, notably when it comes to the Golan recognition. ${ }^{233}$ But critics need to appreciate how close these policies are to the much more widespread position of ignoring or downplaying the significance of Palestinian external self-determination. It is also necessary to appreciate the relevance of the law on the use of force to the questioning of the existence of the occupation itself, as opposed to merely the implications it has for annexation. More fundamentally, it is necessary to appreciate the risk that framing such criticism by affirming the legal status quo might operate as a further distraction technique from the limitations of the current normative order.

The common critique made of international law, including the areas of law this article reviews, is that it may be all well and good, but it is not enforced, because of power imbalances and politics. ${ }^{234}$ The present article foregrounds the existence of such imbalances and political preferences in the law, and the law's role in enabling them. It is for the Palestinian people to decide what is in their best interests in general, and as regards the deployment of international legal arguments and recourse to international legal mechanisms. What the present article has aimed to do is identify some of the issues at stake with the general features of the legal system that might be relevant when such decisions are made. ${ }^{235}$

\footnotetext{
233 Annexation Letter (2020), above $\mathrm{n} 75$.

234 See, e.g., the reported remarks of Mudar Kassis in 2014 Birzeit Conference, above nı6, at 152: "Palestinians have seen little enforcement of international law for ... [political/ power] reasons, and [therefore] international law is of limited use for the Palestinian struggle against Israeli colonialism." See also the remarks of John Dugard, id., at 154 "the main problem is not the law but those who do not act upon the legal rules."

235 For further discussion of different aspects, see, e.g., the works cited above ni6.
} 


\section{Acknowledgments}

Warm thanks are due to Nabila Roukhamieh-McKinna, doctoral student at the UCL Faculty of Laws, for excellent research assistance, and to Ata Hindi of this Journal, for his meticulous editing, and to the participants at the two conferences mentioned in this article, and panels at the Law and Society Association conference, where some of the ideas contained herein were presented, and to the anonymous peer reviewers both at this Journal and in my faculty peer-review college, and to the Editor-in-Chief of this Journal, for their valuable feedback. Warm thanks also to Aseel Albajeh, Ata Hindi, Eitan Diamond, Ellen Saliba, Gëzim Visoka, Marco Longobardo, and Susan Power for kindly sourcing, copying and sending me texts I was unable to obtain through other means. And to Samera Esmeir for kindly giving me the text of her presentation at one of the conferences mentioned in this article, enabling me to cite it herein. My warm thanks also to the following people, with whom I have discussed various aspects of my ideas that have ended up in this article, and have benefited from their insights on them: Laith Abu Zeyad, Matilda Arvidsson, Valentina Azarova, Clive Baldwin, Aslı Bâli, Antal Berkes, Reem Al-Botmeh, James Crawford, Eitan Diamond, Cordula Droege, Noura Erakat, Orna BenNaftali, Smadar Ben Natan, Dana Farraj, Rotem Giladi, Daphna Golan, Shahd Hammouri, Ata Hindi, Ardi Imseis, Shawan Jabarin, Mudar Kassis, Asem Khalil, David Kretzmer, Anne Lagerwall, Eliav Lieblich, Karin Loevy, Itamar Mann, Anna Mykytenko, Fionnuala Ní Aoláin, Munir Nusseibeih, Helena van Roosbroeck, Tom Ruys, Charles Shamas, Diala Shamas, Omar Shakir, Nadera Shalhoub-Kevorkian, Raja Shehadeh, Hala Shoaibi, Janique Thoele, Pål Wrange, and the brilliant students at Birzeit University, Al-Quds University and on my "decolonizing law" LLM course at UCL. This article is dedicated to the memories of James Crawford, Vera Gowlland-Debbas and Chandra Lekha Sriram. 